\title{
Modeling Cutaneous Squamous Carcinoma Development in the Mouse
}

\author{
Phillips Y. Huang and Allan Balmain \\ Helen Diller Family Comprehensive Cancer Center, University of California San Francisco, San Francisco, \\ California 94158 \\ Correspondence: abalmain@cc.ucsf.edu
}

Cutaneous squamous cell carcinoma (SCC) is one of the most common cancers in Caucasian populations and is associated with a significant risk of morbidity and mortality. The classic mouse model for studying SCC involves two-stage chemical carcinogenesis, which has been instrumental in the evolution of the concept of multistage carcinogenesis, as widely applied to both human and mouse cancers. Much is now known about the sequence of biological and genetic events that occur in this skin carcinogenesis model and the factors that can influence the course of tumor development, such as perturbations in the oncogene/tumor-suppressor signaling pathways involved, the nature of the target cell that acquires the first genetic hit, and the role of inflammation. Increasingly, studies of tumor-initiating cells, malignant progression, and metastasis in mouse skin cancer models will have the potential to inform future approaches to treatment and chemoprevention of human squamous malignancies.

$\mathrm{N}_{\mathrm{a}}^{\mathrm{o}}$ nmelanoma skin cancer, comprising SCC and basal cell carcinoma (BCC), is by far the most common cancer among Caucasian people, with a recorded incidence in 2006 of more than 3 million in the U.S. alone (Rogers et al. 2010). Of the two subtypes, SCC is the more aggressive with a significant risk of metastasis, and is associated with greater morbidity and mortality.

SCC most commonly arises on sun-exposed areas of the skin, but is also a feature of several hereditary disorders, including multiple selfhealing squamous epithelioma (MSSE), which afflicts individuals with mutations in the TGFBR1 gene coupled with rare variants in an adjacent region of Chromosome 9q22.3 (Goudie et al. 2011; Kang et al. 2013); a form of XX- male sex reversal that is caused by mutations in the RSPO1 gene (Parma et al. 2006); and a number of diseases characterized by genome instability, such as dyskeratosis congenita (DKC), where SCC may arise as a consequence of elevated genome mutation rates.

Recent somatic mutation analyses of sporadic skin SCCs have revealed frequent mutations in NOTCH1, NOTCH2, TP53, CDKN2A, HRAS, and KRAS (Durinck et al. 2011; Mauerer et al. 2011; Wang et al. 2011). These new studies emphasize the strong similarities between the mutation spectra in human squamous tumors at different sites including the skin, head and neck, and lung (Agrawal et al. 2011; Stransky et al. 2011; The Cancer Genome Atlas Research Network 2012). Although most nonmelanoma

Editors: Anthony E. Oro and Fiona M. Watt

Additional Perspectives on The Skin and Its Diseases available at www.perspectivesinmedicine.org

Copyright (C) 2014 Cold Spring Harbor Laboratory Press; all rights reserved; doi: 10.1101/cshperspect.a013623

Cite this article as Cold Spring Harb Perspect Med 2014;4:a013623 
skin cancer can be successfully treated with surgery and/or chemotherapy, metastatic SCC is associated with an extremely poor long-term prognosis, with a 10 -yr survival rate of $<20 \%$ (Alam and Ratner 2001). To develop better clinical treatments and chemoprevention strategies for SCC, there is a need to achieve a better understanding of the biology of the disease through animal models.

In this review, we describe the mouse models that have been developed to study cutaneous SCC, in particular the DMBA/TPA chemical carcinogenesis model. We discuss how this model has been used to address the central question of target cell for tumor initiation, an effort that has been greatly aided over the years by the development of transgenic mouse technology. Additionally, we discuss how the model has been used to dissect the functions of Ras effectors and to investigate tumor-suppressor pathways that operate to inhibit SCC development. Finally, we describe how the DMBA/TPA model has been used to examine the role of inflammation in skin carcinogenesis.

\section{UV RADIATION CARCINOGENESIS}

Although the majority of mouse skin cancer models involving carcinogens have used chemical mutagens and promoters, it is nevertheless the case that $90 \%$ of nonmelanoma skin cancer is estimated to be attributable to excessive exposure to UV radiation (Grossbart and Lew 1996). To examine whether UV radiation can induce SCC in mice, several groups used hairless but immunocompetent SKH-1 mice, which are well suited for this purpose because they lack the dense, UV-impenetrable hair coat of wildtype mice. Together, these studies showed that UVexposure is capable of inducing SCC in $\mathrm{SKH}$ 1 mice, in a dose-, exposure time-, and wavelength-dependent manner (for review, see Van Kranen and De Gruij 1999). The SCCs that arise commonly have Trp53 mutations, which closely recapitulate the TP53 mutations seen in sporadic human SCCs (van Kranen et al. 1995).

However, it remains unclear what other mutations arise in this model to cooperate with $\operatorname{Trp53}$ mutations in driving tumorigenesis. For instance, while RAS mutations are seen in 3\%$25 \%$ of human SCC cases (Khavari 2006; Durinck et al. 2011; Mauerer et al. 2011), they are extremely rare in this model (van Kranen et al. 1995). Work in this area is hampered by the fact that $S K H-1$ mice have a nonfunctional Hairless $(\mathrm{Hr})$ gene, and although this confers a practical advantage for experiments involving controlled exposure to UV light on a daily basis, the $\mathrm{Hr}$ gene plays an important role in skin metabolism (Kumpf et al. 2012), and its absence may influence the pathways by which tumors develop in this model. The remainder of this review will focus on chemical/genetic models of SCC development.

\section{CHEMICAL INDUCTION OF SKIN TUMORS}

The first links between chemical exposure and the development of skin cancers (Pott 1775) prompted early attempts to develop tractable models for the study of chemically induced skin cancers. Chemical carcinogenesis of the skin has since emerged as the workhorse model of SCC, having been used to test hundreds of individual hypotheses across a wide range of topics in cancer biology. It has played a pivotal role in the evolution of the concept of multistage carcinogenesis, as commonly applied to both human and mouse cancers, and has given rise to the operational definitions of the key tumor processes of initiation, promotion and malignant progression ( for reviews, see Boutwell et al. 1982; Yuspa 2000).

In the most commonly used model, a typical treatment regimen involves first a single topical dose of the carcinogen dimethylbenzanthracene (DMBA), which introduces the initiating mutation to certain cells in the skin. This is then followed by repeated administration of a proinflammatory phorbol ester such as 12 -O-tetradecanoylphorbol-13-acetate (TPA), which promotes the selection and growth of initiated cells into benign tumors known as papillomas (Fig. 1). With time, some of the papillomas will progress to malignant SCCs, which can further disseminate to distant sites via metastasis. Some SCCs can also convert to a more aggressive form of tumor known as spindle carcinoma, 

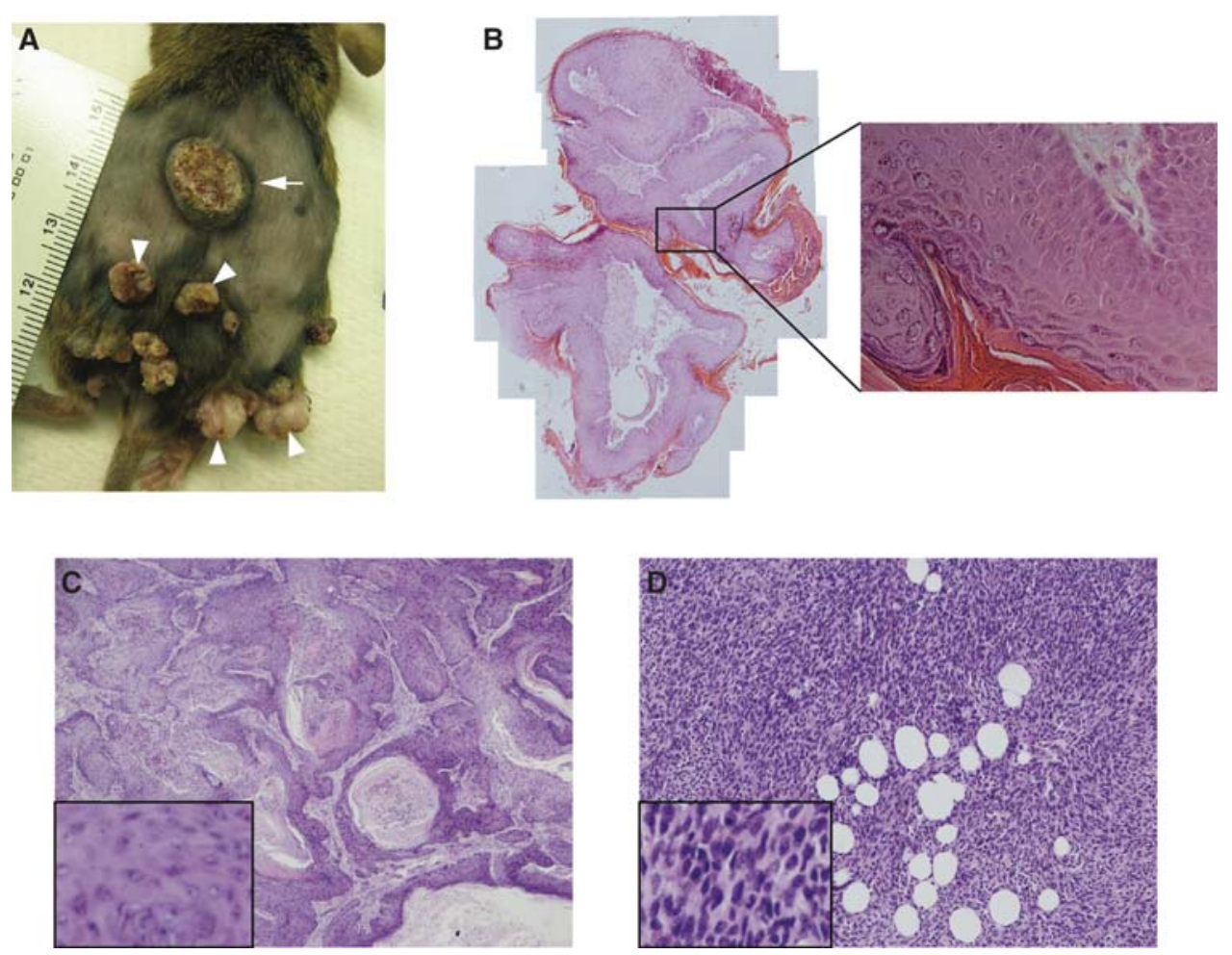

Figure 1. Macroscopic and histological views of cutaneous papillomas and SCCs. (A) Picture of the back skin of a DMBA/TPA-treated mouse showing papillomas (arrowheads) and an SCC (arrow). Note the exophytic, nodular appearance of the papillomas, and the crater-like architecture of the SCC. (B) Papillomas do not breach the underlying epithelial basement membrane and show a high degree of keratinization. $(C)$ Class A tumors include pure squamous cell carcinomas and squamous tumors with a small spindle component. This particular class $\mathrm{A}$ tumor is well-differentiated with heavy keratinization. $(D)$ Class B tumors are mostly pure spindle cell carcinomas, which are poorly differentiated with spindle-shaped cells that resemble fibroblasts. ( $C$ and $D$ are based on data from Wong et al. 2013.)

via epithelial-mesenchymal transition (EMT) (Klein-Szanto et al. 1989). Besides DMBA, other chemical carcinogens that have been used to initiate skin cells include methylnitrosourea (MNU) and 3-methylcholanthrene (MCA), each of which induces carcinogen-specific mutations in Hras (Brown et al. 1990).

Although the two-stage DMBA/TPA model does not mimic the precise sequence of events that occur in spontaneous human SCC, it is highly reproducible and can be easily adapted to test various genetic and environmental factors that may affect tumor development. Moreover, it offers the advantage that the distinct tumor stages can be easily discerned and separately studied in the context of multistage car- cinogenesis. Accordingly, the DMBA/TPA model has been extensively characterized in terms of the series of biological and genetic events that occur during tumor growth.

For instance, a specific mutation in codon 61 of Hras (Q61L) was identified as the initiating mutation in the two-stage mouse skin model (Balmain and Pragnell 1983; Balmain et al. 1984; Quintanilla et al. 1986). Evidence for this includes the demonstration that a viral version of activated Hras is sufficient to induce tumors in infected, TPA-promoted skin (Brown et al. 1986), and the observation that different mutagens produce different activating mutations in Hras, but can all effect tumor initiation (Brown et al. 1990). Interestingly, although RAS 
mutations in general are relatively rare in human SCCs, the recent flurry of whole genome and exome sequencing studies of human cancers have identified the Q61L mutation in HRAS as the most common $R A S$ mutation in squamous cancers of the skin, head and neck, and lung (Agrawal et al. 2011; Durinck et al. 2011; Mauerer et al. 2011; Stransky et al. 2011; Wang et al. 2011).

During the promotion phase, the papillomas that arise frequently show trisomy of chromosome 7 (Aldaz et al. 1989), where the Hras gene is located. Further, the duplicated chromosome is invariably that which bears the mutant Hras allele, which thus suggests a strong preference for amplification of the mutant Hras allele (Bremner and Balmain 1990). SCCs, on the other hand, often show mutation and loss of heterozygosity ( $\mathrm{LOH})$ of the tumor suppressor Trp53 that are not seen in papillomas, which indicates a role for Trp53 mutation or loss in malignant progression (Buchmann et al. 1991; Burns et al. 1991).

Apart from the classical route to squamous carcinoma (henceforth, class A carcinoma) formation outlined above, recent work in our laboratory has uncovered an alternative route to invasive carcinoma (henceforth, class B carcinoma) development (Wong et al. 2013). A genetically heterogeneous population of mice was treated with the DMBA/TPA protocol, and unsupervised hierarchical clustering of the gene expression profiles obtained from $>60$ carcinomas collected from these mice identified two distinct molecular categories. Class A carcinomas include pure squamous cell carcinomas and squamous tumors with a small spindle component, whereas class B carcinomas are the most aggressive carcinomas that develop in the DMBA/TPA model, composed primarily of pure spindle cell carcinomas. As expected from their spindle morphology, class B carcinomas express EMT markers, such as Snail, Zeb1, and Vimentin; however, unlike class A carcinomas, class B carcinomas are characterized by loss of the Ink4/Arf locus and have, paradoxically, down-regulated components of the canonical HRas signaling pathway despite their increased invasiveness (although Mapk and Akt signaling remain elevated). Class $\mathrm{B}$ carcinomas are also less dependent on inflammation for their formation (discussed in detail later), and thus may represent a different category of tumors that diverge from the class A pathway soon after initiation or arise from a separate target cell altogether (Fig. 2).

The vast body of scientific work utilizing the DMBA/TPA model gives us the unique opportunity to compare and dissect the influence of many biological and genetic factors on tumor development. Nevertheless, when attempting to interpret the results of various DMBA/TPA studies, one should bear in mind the important caveat that mouse strain background has a considerable influence on tumor susceptibility and outcome. For instance, Mus spretus and C57BL/ 6 mice are known to be tumor-resistant, whereas $\mathrm{FVB} / \mathrm{N}$ mice have been shown to be skin tumor-susceptible (Hennings et al. 1993). The difference in sensitivity between C57BL/6 and FVB/N mice to Ras-induced skin carcinogenesis, for instance, has been mapped to a polymorphism in the Ptch gene, which affects binding to the tumor suppressor Tid1 and consequently Ras-induced apoptosis (Wakabayashi et al. 2007). Hence, without prior knowledge of the mouse genetic backgrounds involved, one should exercise some caution when comparing the effects observed in different studies.

\section{TARGET CELL FOR INITIATION}

The identity and nature of the target cell that acquires the first genetic hit leading to initiation is a central question in cancer biology (for review, see Perez-Losada and Balmain 2003). Many tumors contain rare cells that express stem cell markers and are capable of long-term self-renewal; these cells have also been shown to initiate secondary tumors in limiting dilution transplantation assays and even generate large parts of the tumor in situ (Chen et al. 2012; Driessens et al. 2012; Lapouge et al. 2012; Schepers et al. 2012). Together, these observations are compatible with the notion of so-called "cancer stem cells," which act as tumor cells of origin and fuel the growth of the tumor (Lapidot et al. 1994). Further, it has been hypothesized 


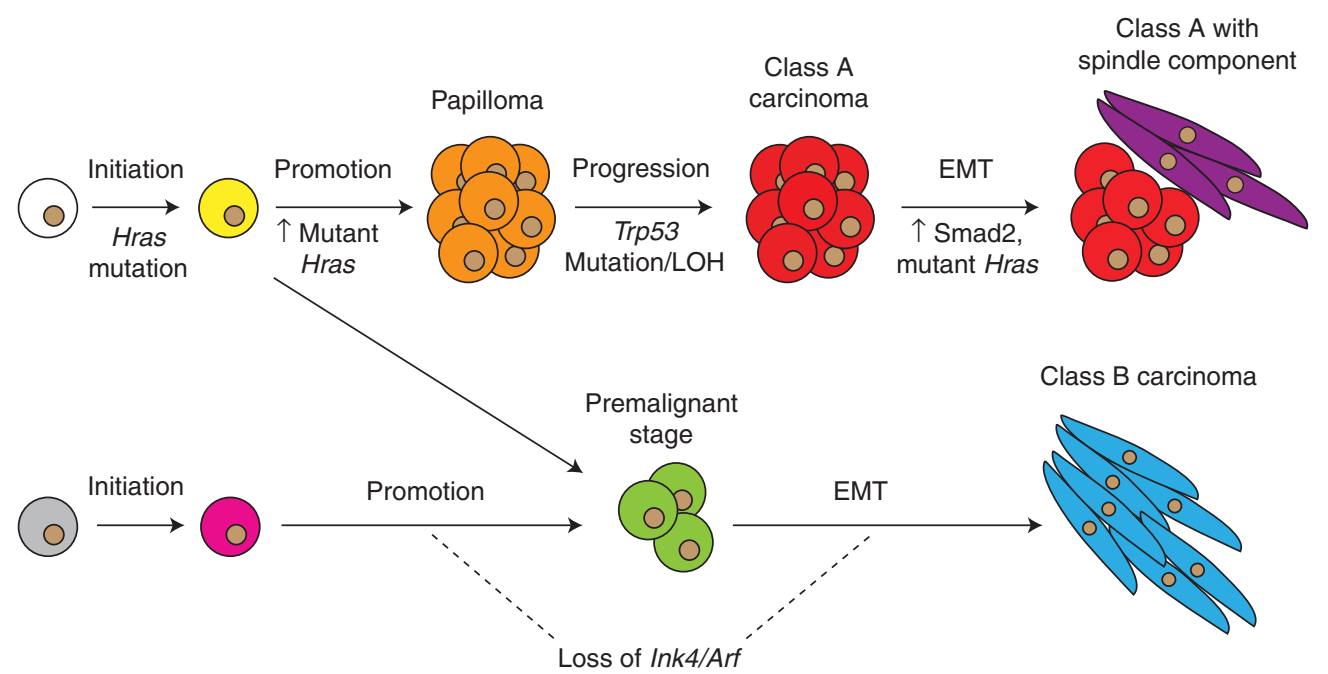

Figure 2. Genetic and molecular events during multistage skin carcinogenesis. Class A and class B carcinomas may arise from the same target cell, but diverge soon after initiation resulting in different premalignant stages. Alternatively, class A and class B carcinomas may come from distinct target cells, with possibly different initiating mutations in these cells. Spindle carcinoma formation via the class A route is thought to involve increased mutant Hras levels and nuclear accumulation of Smad2 (Oft et al. 2002); in contrast, in class B spindle carcinomas, mutant Hras levels are down-regulated instead.

that they arise from normal adult stem cells that become transformed during the tumor initiation phase, because both cell populations have a high capacity for self-renewal and clonogenic growth. However, it remains possible that cancer stem cells may actually originate from the initiation of more committed progenitor cells, which only acquire stem cell-like characteristics after undergoing oncogenic insult or exposure to inflammatory stimuli (for review, see Gupta et al. 2009; Gonzalez-Suarez et al. 2010; Schramek et al. 2010).

One of the first studies to shed light on this question of the target cell for initiation in the DMBA/TPA model was performed by Berenblum and Shubik (1949). The authors initiated mouse skin tumors with DMBA but allowed 1 yr to elapse before treating the mice repeatedly with croton oil ( from which TPA was eventually isolated). They observed that papillomas developed with approximately the same latency and yield as they did in control mice that were treated immediately with the promoter, indicating that the initiated cells remained in the skin for most of the murine lifespan. This central find- ing of the "permanence" of the initiating event was subsequently corroborated by other groups, who accounted for confounding factors such as age at time of promotion (Van Duuren et al. 1975) and used intragastric DMBA administration to avoid topical DMBA-induced wound healing, which is thought to possess promoting activity (Loehrke et al. 1983). Importantly, these demonstrations that initiated cells can reside in the skin for long periods of time without giving rise to visible lesions until selection and growth through promotion are consistent with stem cells being the initiated target cells, as only stem cells have the self-renewal potential to allow for such long-term persistence (although, as noted above, it remains possible that stem cell properties may be induced by oncogenic events).

Another early study to address the question of target cell uses the process of epidermal abrasion, which involves using a tool, such as a motorized felt wheel, to remove the interfollicular epidermis (IFE) while leaving the hair follicles intact (Argyris 1985). This process will remove all the terminally differentiating cells in the IFE, while sparing the various stem cell populations 
that have been shown to reside in the hair follicle (for review, see Jaks et al. 2010). One week after initiation with DMBA, mice were either abraded as the experimental group or left unabraded as the control group; TPA treatment was then started 4 wk later, when the IFE had regenerated from cells in the hair follicles and returned to normal (Morris et al. 2000). In this study, the authors observed that abraded mice developed far fewer papillomas than unabraded mice; however, the carcinoma responses of the two groups were similar. One interpretation of these data is that benign papillomas arise from initiated cells in the IFE, while most malignant SCCs arise from initiated cells in the hair follicle (including possibly stem cells). Together, these early studies point to a role for the identity of the target cell in influencing the course of tumor development.

\section{TRANSGENIC MICE AND SCC DEVELOPMENT}

With the advent of transgenic mouse technology (for reviews, see Palmiter and Brinster 1986; Hanahan et al. 2007) and the cloning of keratin promoters capable of directing transgene expression to specific skin compartments (Vassar et al. 1989; Fuchs et al. 1992; Byrne and Fuchs 1993), it soon became possible to target oncogenes to subpopulations of cells in the skin, to test the ability of these cells to initiate tumor formation. Early examples of this approach were the demonstrations that targeting of mutant Hras to even terminally differentiating cells in the skin (using the K10 or K1 promoter) could give rise to papillomas, which, however, did not progress to malignancy (Bailleul et al. 1990; Greenhalgh et al. 1993). In contrast, when mutant Hras was expressed in the outer root sheath (ORS) of the hair follicle (using a truncated version of the $K 5$ promoter), where stem cells have been shown to reside, malignant SCCs and spindle carcinomas arose (Brown et al. 1998).

One common criticism of these early transgenic mouse studies is that the oncogene of interest was vastly overexpressed in subpopulations of cells. This problem can now be circum- vented through knock-in of mutant alleles into their endogenous loci, which allows the mutant alleles to be subsequently activated in subsets of cells via removal of a Stop cassette by a tissue-specific Cre recombinase (Jackson et al. 2001). Using this approach, several groups targeted the expression of an activated form of Kras (KrasG12D) to different cell populations within the skin (Caulin et al. 2007; Lapouge et al. 2011; White et al. 2011). When oncogenic Kras was expressed in terminally differentiating suprabasal cells of the IFE (using Involucrin-Cre), or cell populations with stem cell characteristics such as basal keratinocytes (using K5-Cre) and hair follicle bulge stem cells (using K15-Cre or K19-Cre), papillomas developed. However, when oncogenic Kras was expressed in transit amplifying hair matrix cells (using Shh-Cre) (Lapouge et al. 2011; White et al. 2011), no papillomas arose. More recently, expression of KrasG12D in hair follicle junctional zone stem cells (Jensen et al. 2009) using Lrig1-Cre has also been shown to be capable of giving rise to papillomas when combined with full-thickness back wounding (Page et al. 2013). Importantly, although these studies reinforce the idea that the identity of the target cell has a role to play in determining the course of tumor development, they also indicate a certain degree of plasticity among different stem cell populations during tumorigenesis, such that many of them are capable of giving rise to tumors when engineered to express an appropriate oncogene.

An interesting feature of these oncogenetargeting studies is that activation of Ras gives rise to tumors generally in the dorsal skin, but not usually in the tail skin, despite the activity of promoters of genes such as K14 and Involucrin in tail epidermis (Youssef et al. 2010; Lapouge et al. 2011; White et al. 2011; Gomez et al. 2013). These data are compatible with previous observations of resistance of tail skin to DMBA/TPA carcinogenesis (Schweizer and Marks 1977). The reasons for this discrepancy between tail skin and back skin may give us additional information about the nature of the target cells for carcinogenesis, particularly as activation of the Smoothened (Smo) gene using the same K14 promoter gives rise to basal cell carcinomas (BCCs) 
predominantly in tail but not in dorsal epidermis (Youssef et al. 2010).

A final point of contention with transgenic mouse studies is that oncogene activation generally occurs in whole populations of cells in the targeted cell compartment, rather than in the clonal fashion that presumably characterizes spontaneous or carcinogen-induced tumors. The fact that a particular cell compartment is capable of giving rise to tumors when engineered to express an oncogene is not synonymous with those cells being bona fide target cells during carcinogen-induced tumor development. Single initiated cells carrying Ras mutations may have to "outcompete" their neighbors to expand within the stem cell niche (Vermeulen et al. 2013) and this restriction is presumably absent after coordinated activation of a Ras oncogene in multiple cells within a compartment. A better approach to study the target cell for initiation may be to use neutral labeling methods to mark the potential target cell a priori, followed by carcinogen treatment and lineage tracing of progeny cells that carry the permanent label during subsequent tumor development.

An early study used a neutral labeling approach to address the question of whether chemically induced skin papillomas have a polyclonal origin (Winton et al. 1989). The authors first generated chimeric mice by aggregating embryos of two different strains. These mice show mosaicism in their tissues, including skin. By subjecting these mice to the DMBA/TPA protocol and performing immunohistochemical analyses, the authors were able to show that about $30 \%$ of the papillomas that arose have a mixture of cells from both parent embryos. Hence, they conclude that a significant proportion of papillomas are polyclonal in origin. A similar approach was adopted by Arwert et al. (2010) to investigate the contribution of terminally differentiating cells to tumorigenesis in InvEE mice, which overexpress activated Mek1 in the suprabasal layer of the IFE. Here, the authors generated chimeras by aggregating InvEE embryos and GFP-positive embryos, and showed that proliferative, transgene-negative (but GFP-positive) cells are fully incorporated into the tu- mors that develop on wounding; these transgene-negative cells thus actively contribute to tumor formation, and are stimulated to do so by non-cell-autonomous signals from the Mek1expressing, terminally differentiating cells.

More recently, a neutral labeling method was also used to determine if bulge stem cells are the cells of origin of chemically induced skin tumors (Li et al. 2012). In this study, the authors initiated Krt1-15CrePR1;R26R mice with DMBA, then activated Cre recombinase with the drug RU486 1 wk later; finally, tumor promotion was performed with biweekly administration of TPA for $20 \mathrm{wk}$. When the authors collected tumors from the mice and performed LacZ staining to trace the progeny of the $\mathrm{K}^{+} 5^{+}$ bulge stem cells, they observed that all papillomas after 20 wk of TPA treatment contained a mixture of nonblue and blue cells, with the latter making up, on average, $\sim 30 \%$ of papilloma cross-section area. This suggests that $\mathrm{K}^{+} 5^{+}$ stem cells may have the potential to contribute long-term to papillomas in the DMBA/TPA model. However, there are a few caveats to this study. One, there is a significant level of promoter leakiness in the Krt1-15CrePR1;R26R mice, which makes it difficult to determine the true contribution of the $\mathrm{K} 5^{+}$stem cells to papillomas. Second, Cre recombinase was activated only after DMBA treatment, in which case initiated progenitor cells may acquire stem cell properties and start expressing K15 de novo. Finally, microdissection suggested that even in papillomas containing blue marked cells, only $30 \%$ of these labeled cell populations carried the known Hras initiating mutation. It is presently unclear whether this interesting heterogeneity is caused by technical issues or has a real biological basis.

Another recent study that uses a similar but distinct approach was performed by Driessens et al. (2012). They treated K14CreER/Rosa-YFP mice with the DMBA/TPA protocol and then initiated lineage tracing in the resulting papillomas and SCCs at clonal density, by administering a low dose of tamoxifen (Driessens et al. 2012). Through 3D reconstruction of whole clones from serial sections, they report the existence of two proliferative cell compartments in papillomas, mirroring the hierarchy seen in 
normal tissues - a slower-cycling "progenitor cell" fraction that is shorter-lived and gives rise to smaller clones, and a faster-cycling "stem cell" fraction that persists longer and gives rise to larger clones. In contrast, in SCCs, the authors report the existence of a single proliferative cell population that expands geometrically and has a low probability of terminal differentiation. One caveat to this study is that the lineage tracing results reported are for relatively short periods of time ( $9 \mathrm{~d}$ for SCCs, and up to $7 \mathrm{wk}$ for papillomas). It remains to be seen if the same tracing patterns will hold up over longer periods of time and qualify the observed proliferative cell compartments as arising from bona fide cancer stem cells. Moreover, because lineage tracing is only initiated after tumor formation, several important questions remain outstanding. For example, what is the relationship of the $\mathrm{K}_{14}{ }^{+}$proliferative cell populations reported in this study to stem cell compartments in normal skin? Also, what is the nature of the target cells that lead to benign or malignant tumors and how may these differ?

Taking into account all the studies described in this and the preceding section, a picture emerges of the existence of a continuum of target cells amenable to initiation. Here, the course of tumor development, in terms of cell fate decisions and malignant potential, is likely a function of both the nature of the initiating mutation and the identity of the target cell. Hence, although initiated terminally differentiating cells are capable of giving rise to papillomas, these often lack the propensity to progress to malignancy; ultimately, the promotion of initiated multipotent stem cells may be required to induce malignant SCCs.

\section{RAS EFFECTORS IN SKIN CARCINOGENESIS}

The highly reproducible mutational activation of Hras in the DMBA/TPA model, together with the demonstration of the causality of this event in initiating carcinogenesis, has led to the widespread use of this model for testing the functional roles of a wide variety of components of the Ras signaling pathway. Besides mutant Hras, transgenic expression of a number of upstream activators of Ras in the skin has also been reported to be capable of inducing tumors. In particular, mice that overexpress TGF- $\alpha$ in their epidermis develop papillomas on wounding or TPA treatment (Vassar et al. 1992; Dominey et al. 1993). TGF- $\alpha$ is the ligand for the EGF receptor, which activates Ras through the guanine nucleotide exchange factor SOS (Fig. 3). Importantly, the papillomas that arise in TGF- $\alpha$ transgenic mice do not have a mutation in Hras, which suggests that activation of the Ras pathway through TGF- $\alpha$ overexpression is sufficient to induce skin tumor initiation in the absence of Hras mutational activation. Consistent with this idea, most sporadic human SCCs show activated Ras signaling, despite Ras being mutationally activated in only a small subset of these tumors (references above). Interestingly, the papillomas from the TGF- $\alpha$ transgenic mice also have the tendency to regress and were never observed to progress to malignancy. More recently, K5-SOS-F transgenic mice that overexpress a dominant form of SOS in basal keratinocytes were generated and these develop spontaneous papillomas with $100 \%$ penetrance (Sibilia et al. 2000).

The roles of Raf-MAPK and PI3K-Akt signaling downstream from Ras have been extensively characterized. Raf- 1 is the first identified and most intensively studied Ras effector. It activates mitogenic MAPK signaling, leading to induction of the Ets family of transcription factors and Cyclin D1. PI3K-Akt signaling, on the other hand, activates mTOR, with downstream consequences for protein synthesis and cell growth. Apart from Raf- 1 and PI3K, Ras has a number of other known effectors (Fig. 3; Table 1) whose in vivo functions remain relatively poorly understood. Here, use of the DMBA/ TPA model has again been instructive.

For instance, Ras binds and activates PLC- $\varepsilon$, which produces the second messengers diacylglycerol and inositol 1,4,5-triphosphate. These, in turn, activate protein kinase $\mathrm{C}$ (PKC) and mobilize intracellular calcium, respectively. PKC is known to have a role in skin tumor promotion, because TPA is known to bind and regulate PKC (Castagna et al. 1982; Fournier and Murray 


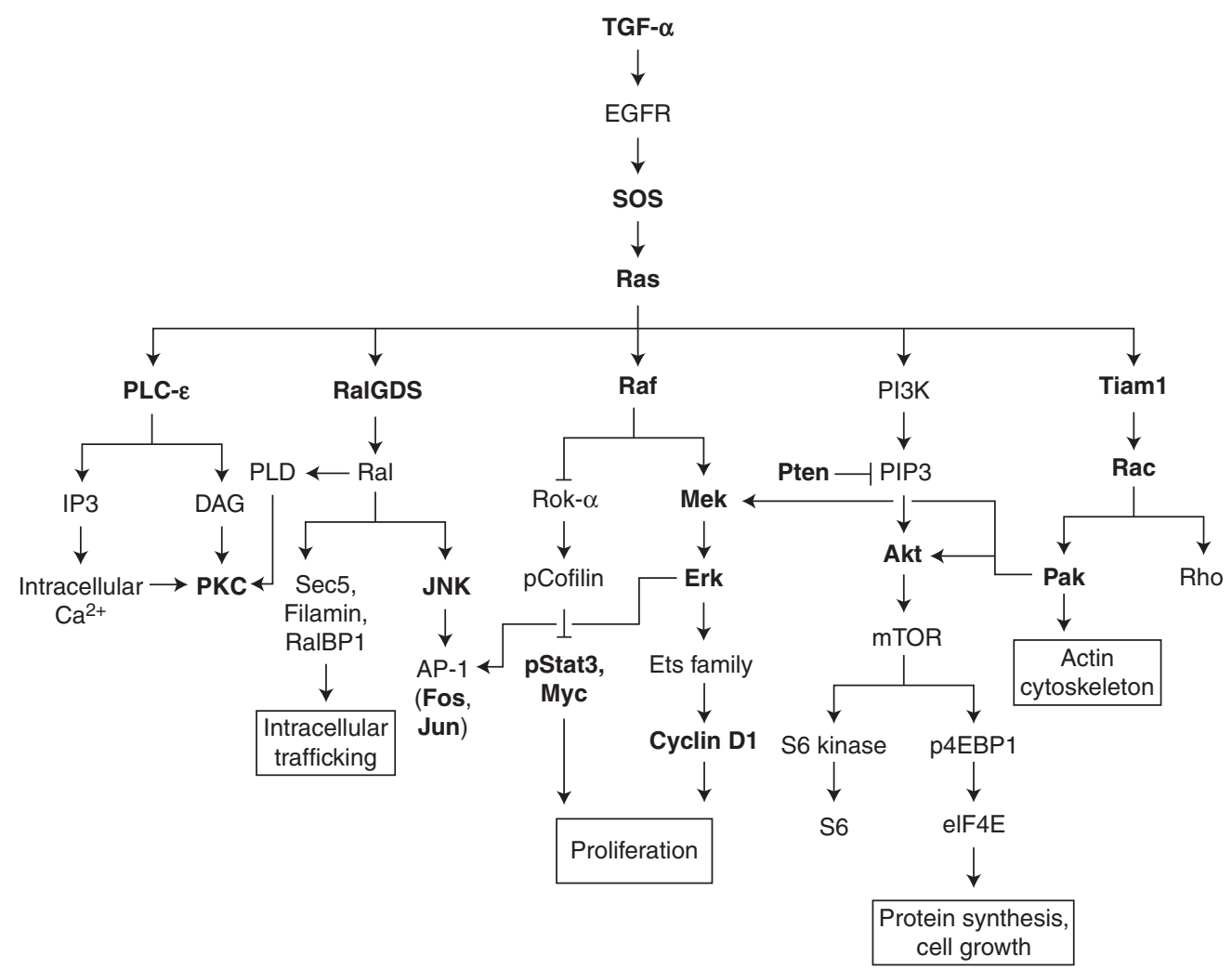

Figure 3. Ras effector pathways in skin carcinogenesis. Signaling components in bold have been directly investigated for their in vivo functions during skin tumor development. The roles of TGF- $\alpha$, SOS, Ras, PLC- $\varepsilon$, RalGDS, Raf-1, Stat3, Pten, and Tiam1 are described in detail in the text. The rest are summarized in Table 1.

1987; Hansen et al. 1990), which in turn suggests a potential role for $P L C-\varepsilon$ in tumorigenesis downstream from Ras activation. When treated with the DMBA/TPA protocol, $P L C$ - $\varepsilon$-deficient mice developed papillomas with increased latency, reduced yield and a decreased propensity to undergo malignant conversion (Bai et al. 2004). This indicates that PLC- $\varepsilon$ has far-ranging roles in skin carcinogenesis, impinging on both the promotion and malignant progression stages.

Ras also binds and activates Tiam1, which is a guanine nucleotide exchange factor that in turn activates Rac GTPases. In vitro, Rac GTPases are implicated in cell migration and cell-cycle progression (Olson et al. 1995, 1998; Hordijk et al. 1997; Keely et al. 1997). When treated with the DMBA/TPA protocol, Tiam $1^{-/-}$mice were resistant to tumor devel- opment, and this was attributed to increased apoptosis during the initiation stage and reduced proliferation during the promotion stage (Malliri et al. 2002). However, Tiam $1^{-/-}$mice also had a higher ratio of malignant to benign tumors, which thus indicates a biphasic role for Tiam1 in skin carcinogenesis. Interestingly, Tiam 1 is down-regulated in class B carcinomas (Wong et al. 2013). Hence, while papilloma formation via the classical route is impeded by Tiam 1 deficiency, the higher percentage of malignant tumors seen in DMBA/TPA-treated Tiam $1^{-/-}$mice could be a reflection of their origin as class B carcinomas. Indeed, when the authors treated Tiam $1^{-/-}$mice with an alternative carcinogenesis protocol that involved repeated treatment with DMBA in the absence of TPA (known as the complete carcinogenesis protocol), they obtained a higher percentage of 
P.Y. Huang and A. Balmain

Table 1. Summary of the in vivo functions of select genes downstream from Ras during skin carcinogenesis

\begin{tabular}{|c|c|c|c|}
\hline Gene & Mouse model & Phenotype & References \\
\hline \multirow[t]{2}{*}{$A k t$} & Akt1 knockout & $\begin{array}{l}\text { In the DMBA/TPA model, } A k t 1^{-/-} \text {mice } \\
\text { develop tumors with reduced yield and size }\end{array}$ & Skeen et al. 2006 \\
\hline & $\begin{array}{l}\text { Overexpression of wild-type } \\
\text { and constitutively active } \\
\text { Akt } 1 \text { in the basal layer of } \\
\text { stratified epithelia using the } \\
\text { bovine } K 5 \text { promoter }\end{array}$ & $\begin{array}{l}\text { Epidermal hyperplasia and hyperkeratosis, } \\
\text { and enhanced keratinocyte proliferation in } \\
\text { response to TPA treatment; heightened } \\
\text { tumor susceptibility in the DMBA/TPA } \\
\text { model }\end{array}$ & $\begin{array}{l}\text { Segrelles et al. } \\
\quad 2007\end{array}$ \\
\hline Cyclin D1 & Cyclin D1 knockout & $\begin{array}{l}\text { Cyclin } D 1^{-/-} \text {mice develop papillomas with } \\
\text { increased latency and reduced incidence } \\
\text { and yield in the DMBA/TPA model }\end{array}$ & Robles et al. 1998 \\
\hline Erk & Erk1 knockout & $\begin{array}{l}\text { Erk1 } 1^{-1-} \text { mice show reduced skin } \\
\text { inflammation and proliferation in response } \\
\text { to TPA treatment and are tumor-resistant } \\
\text { in the DMBA/TPA model }\end{array}$ & $\begin{array}{l}\text { Bourcier et al. } \\
\quad 2006\end{array}$ \\
\hline \multirow[t]{2}{*}{ Fos } & c-fos knockout & $\begin{array}{l}c \text {-fos-deficient papillomas quickly become } \\
\text { dry and hyperkeratinized, and fail to } \\
\text { progress to malignancy }\end{array}$ & Saez et al. 1995 \\
\hline & $\begin{array}{l}\text { K5-driven overexpression of a } \\
\text { dominant-negative form of } \\
\text { c-fos }(A-F o s)\end{array}$ & $\begin{array}{l}\text { Mild alopecia and sebaceous gland } \\
\text { hyperplasia; when subjected to chemical } \\
\text { carcinogenesis, mice develop } \\
\text { predominantly sebaceous adenomas }\end{array}$ & Gerdes et al. 2006 \\
\hline Jnk & $J n k 1$ and $J n k 2$ knockouts & $\begin{array}{l}\text { In the DMBA/TPA model, } J n k 1^{-/-} \text {mice } \\
\text { show enhanced tumor susceptibility while } \\
J n k 2^{-/-} \text {mice are tumor resistant }\end{array}$ & $\begin{array}{l}\text { Chen et al. } 2001 ; \\
\text { She et al. } 2002\end{array}$ \\
\hline \multirow[t]{2}{*}{ Jun } & $\begin{array}{l}c \text {-jun knockout in the } \\
\text { epidermis using K5-Cre }\end{array}$ & $\begin{array}{l}\text { In the K5-SOS- } F \text { skin tumor model, } c-j u n \\
\text { ablation leads to smaller papillomas that } \\
\text { show increased differentiation, possibly } \\
\text { caused by down-regulation of EGFR }\end{array}$ & Zenz et al. 2003 \\
\hline & $\begin{array}{l}\text { Transgenic expression of a } \\
\text { dominant-negative form of } \\
\text { c-jun (TAM67) in the basal } \\
\text { epidermis (using the } K 14 \\
\text { promoter) or in the } \\
\text { suprabasal epidermis } \\
\text { (using the Involucrin } \\
\text { promoter) }\end{array}$ & $\begin{array}{l}\text { K14-TAM67 mice have no apparent } \\
\text { epidermal defect but TAM67 expression in } \\
\text { the suprabasal epidermis results in } \\
\text { keratinocyte hyperproliferation and } \\
\text { delayed differentiation; in the DMBA/TPA } \\
\text { model, papillomagenesis is strongly } \\
\text { inhibited in both transgenic mice }\end{array}$ & $\begin{array}{l}\text { Young et al. 1999; } \\
\text { Rorke et al. } \\
2010\end{array}$ \\
\hline \multirow[t]{2}{*}{ Mek } & $\begin{array}{l}\text { Overexpression of Mek1 in } \\
\text { basal keratinocytes and hair } \\
\text { follicle ORS using the K14 } \\
\text { promoter }\end{array}$ & $\begin{array}{l}\text { Epidermal hyperplasia and spontaneous skin } \\
\text { tumor formation }\end{array}$ & Feith et al. 2005 \\
\hline & $\begin{array}{l}\text { Mek2 knockout and } \\
\text { conditional Mek1 knockout } \\
\text { using K14-Cre }\end{array}$ & $\begin{array}{l}\text { In the DMBA/TPA model, Mek1 knockout } \\
\text { but not Mek2 knockout impedes } \\
\text { tumorigenesis; in a mouse model of } \\
\text { oncogenic Ras-driven skin cancer; } \\
\text { however, both Mek1 and Mek2 (or at least } \\
\text { one copy of each) have to be deleted to } \\
\text { impede carcinogenesis }\end{array}$ & $\begin{array}{l}\text { Scholl et al. } \\
\text { 2009a,b }\end{array}$ \\
\hline
\end{tabular}


Modeling Cutaneous SCC

Table 1. Continued

\begin{tabular}{|c|c|c|c|}
\hline Gene & Mouse model & Phenotype & References \\
\hline \multirow[t]{2}{*}{$M y c$} & $K 5-M y c$ transgenic mice & $\begin{array}{l}\text { Spontaneous papilloma and SCC } \\
\text { development; mice are also more tumor } \\
\text { susceptible in the DMBA/TPA model }\end{array}$ & $\begin{array}{l}\text { Rounbehler et al. } \\
2001\end{array}$ \\
\hline & $\begin{array}{l}\text { K14-driven } M y c \\
\text { overexpression }\end{array}$ & $\begin{array}{l}\text { Epidermal hyperplasia, enlarged sebaceous } \\
\text { glands, spontaneous skin lesions and stem } \\
\text { cell loss; DMBA/TPA-treated K14-Myc } \\
\text { mice develop tumors with reduced latency } \\
\text { and increased yield, but these are } \\
\text { predominantly sebaceous adenomas }\end{array}$ & $\begin{array}{l}\text { Arnold and Watt } \\
\text { 2001; Waikel } \\
\text { et al. 2001; } \\
\text { Honeycutt et al. } \\
2010\end{array}$ \\
\hline Pak1 & Pak1 knockout & $\begin{array}{l}\text { Pak1 deficiency impedes tumor development } \\
\text { and progression in a mouse model of } \\
\text { KrasG12D-driven skin cancer }\end{array}$ & Chow et al. 2012 \\
\hline$P K C$ & $\begin{array}{l}P K C-\eta \text { knockout; } K 5 \text {-driven } \\
P K C-\alpha \text { overexpression; } \\
K 14 \text {-driven } P K C-\delta \text { or } \\
P K C-\varepsilon \text { overexpression }\end{array}$ & $\begin{array}{l}\text { In the DMBA/TPA model, } P K C-\eta^{-/-} \text {and } \\
K 5-P K C-\alpha \text { mice show enhanced tumor } \\
\text { formation; K14-PKC- } \delta \text { and } K 14-P K C-\varepsilon \\
\text { mice, on the other hand, are resistant to } \\
\text { papilloma development; K14-PKC- } \varepsilon \text { mice } \\
\text { also show increased de novo carcinoma } \\
\text { formation }\end{array}$ & $\begin{array}{l}\text { Reddig et al. 1999, } \\
\text { 2000; Chida } \\
\text { et al. 2003; } \\
\text { Cataisson et al. } \\
2009\end{array}$ \\
\hline Rac1 & $\begin{array}{l}\text { Keratinocyte-specific deletion } \\
\text { using K5- and K14-Cre }\end{array}$ & $\begin{array}{l}\text { Hair follicle (and epidermal) stem cell loss/ } \\
\text { impairment; } \text { K5-driven Racl ablation leads } \\
\text { to tumor-resistance in the DMBA/TPA } \\
\text { model, associated with a decrease in } \\
\text { keratinocyte proliferation }\end{array}$ & $\begin{array}{l}\text { Keely et al. 1997; } \\
\text { Benitah et al. } \\
\text { 2005; Chrostek } \\
\text { et al. 2006; } \\
\text { Wang et al. } 2010\end{array}$ \\
\hline
\end{tabular}

high-grade, poorly differentiated SCCs, which may represent class B carcinomas.

Another guanine nucleotide exchange factor downstream from Ras is RalGDS, which activates the Ral GTPase. In vitro, Ral is involved in intracellular trafficking and regulating gene expression through transcription factors such as AP-1 (Kops et al. 1999; Nakashima et al. 1999; de Ruiter et al. 2000; Moskalenko et al. 2002). DMBA/TPA treated RalGDS-deficient mice had reduced tumor incidence, size and malignant progression (González-García et al. 2005). Further, RalGDS was reported to mediate survival through the JNK/SAPK signaling pathway, so that heightened apoptosis was observed in the papillomas that arose in RalGDS-deficient mice.

Finally, a novel function of Raf-1 was more recently characterized by studying mice with epidermis-specific Raf-1 deficiency. These mice show hyperactivity of the $\rho$ effector Rok- $\alpha$ in their skin, while Erk activation is unaffected by
Raf-1 ablation (Ehrenreiter et al. 2005). When treated with the DMBA/TPA protocol, Raf-1deficient mice were resistant to tumor development; further, induction of Raf-1 ablation only after tumors had already developed resulted in tumor regression (Ehrenreiter et al. 2009). This addiction of SCCs to Raf-1 was attributed to Raf-1's role in binding and inhibiting Rok- $\alpha$, which prevents Rok- $\alpha$ from phosphorylating and inactivating cofilin; when active, cofilin is able to stimulate Stat3 phosphorylation and Myc expression, leading to proliferation. Hence, when Raf- 1 is ablated in mice, Stat3 phosphorylation and Myc expression will be turned off, so that differentiation predominates over proliferation and tumorigenesis is impeded.

Therefore, apart from its well-documented role in tumor initiation, Ras also has diverse and complex functions that range across multiple stages of skin carcinogenesis. Depending on the particular Ras effector ablated, specific arms of these Ras responses will be abrogated, leading 
P.Y. Huang and A. Balmain

to varied, nuanced consequences for tumor development.

\section{KNOCKOUT MICE AND TUMOR- SUPPRESSOR PATHWAYS}

As with the marriage of transgenic mouse technology to oncogene research in the previous decade, the development of knockout mouse technology in the 1990s made it possible to assess the functions of tumor suppressors in vivo (for review, see Jacks 1996). A subsequent major advance in the field was the invention of CreLox technology, which made it possible to target tumor-suppressor ablation to subpopulations of cells, by flanking the gene of interest with LoxP sites and activating its removal with Cre recombinase specifically in subsets of cells. Further development of an inducible form of the Cre recombinase allowed for postnatal gene deletion at any time of the researcher's choosing.

This knockout mouse technology has been extensively used to interrogate the functions of a number of tumor-suppressor pathways using the DMBA/TPA model. TP53 is frequently mutated in spontaneous human SCC and, as described earlier, is also commonly mutated or lost in SCCs that arise in the DMBA/TPA model. When $\operatorname{Tr} p 53^{+/-}$mice were treated with the DMBA/TPA protocol, papillomas developed with approximately the same latency, yield and size as they did in wild-type mice (Kemp et al. 1993). However, these papillomas progressed more rapidly to SCCs, and malignant conversion was associated with loss of the remaining copy of wild-type Trp53; DMBA/TPA-treated Trp53 $53^{-/}$mice, on the other hand, had a reduced yield of papillomas but these progressed even more rapidly to malignancy. Hence, Trp53 does not appear to have a major role in the initiation or promotion phase of tumor development; rather, loss of Trp53 is associated with malignant progression. In line with these observations, restoration of p53 activity was shown to have no effect on early stage tumors but caused regression of late stage tumors in a mouse model of KrasG12D-driven lung adenocarcinoma (Feldser et al. 2010; Junttila et al. 2010). Additionally, in the KrasG12D-driven skin tumor mouse models described earlier, oncogenic Kras alone can only give rise to papillomas, with no evidence of malignant progression; instead, oncogenic Kras driven by K5, K15, or K19 has to be coupled to $\operatorname{Trp} 53$ deficiency to induce malignant SCCs.

Apart from promoting the malignant conversion of papillomas, Trp53 loss can have other effects that are also consistent with an increased frequency of malignant tumors. For instance, Trp53 loss may lead to increased numbers of stem cells, and hence an expansion of the pool of target cells that may specifically give rise to malignant tumors. In support of this hypothesis, Trp53 loss has been shown to increase the self-renewal of both mammary and neural stem cells (Meletis et al. 2006; Cicalese et al. 2009). In particular, p53 regulates the polarity of cell division in mammary stem cells, with Trp53 loss predisposing toward self-renewing symmetric cell divisions. Remarkably, mammary tumor stem cells also show an elevated frequency of symmetric cell divisions, and restoration of p53 activity rescues asymmetric stem cell divisions and results in tumor growth reduction. Importantly, stem cell numbers increase progressively in premalignant Trp53-/- murine mammary gland over time. In the context of the epidermis, various models have been proposed to account for how stem cells in the basal layer proliferate and self-renew in maintaining the tissue (Potten 1981; Potten et al. 1982; Clayton et al. 2007; Mascré et al. 2012). Like mammary stem cells, epidermal stem cells are capable of both asymmetric and symmetric cell divisions. If Trp53 loss in the epidermis similarly favors self-renewing symmetric stem cell divisions at the expense of asymmetric stem cell divisions, then we might also expect stem cell numbers to increase in $\operatorname{Trp53} 3^{-/-}$skins.

Yet another area where Trp53 loss can have an effect is cell competition. This phenomenon was first described in Drosophila melanogaster, where cells of two different genotypes within a common developmental niche were shown to compete with each other for tissue occupancy (Morata and Ripoli 1975); at the cell population level then, cell competition can be described as a process of natural selection of the fittest cells. 
The same principle has since been shown to govern cell-cell interactions in many tissue types and organisms, including mammals. For instance, ionizing radiation (IR)-induced stress has been shown to be capable of eliciting cell competition within the hematopoietic stem cell (HSC) compartment (Bondar and Medzhitov 2010); in particular, by generating mice with a mosaic pattern of p53 deficiency within the HSC compartment, the authors of the study showed that in the presence of IR stress, p53deficient HSCs have a selective proliferative advantage and induce a senescence-like phenotype in outcompeted HSCs with higher levels of p53 activity. More recently, a genome-wide screen in murine induced pluripotent stem cells similarly identified p53 as a key gene whose down-regulation created "cheater" cells that outcompete wild-type cells during pluripotent stem cell differentiation in vitro and in vivo (Dejosez et al. 2013).

In the context of the skin, UV exposure in both mice and humans gives rise to patches of normal-looking cells that contain mutant p53, which suggests that p53 mutation is an early event in the development of UV-induced SCC (Berg et al. 1996; Jonason et al. 1996; Ren et al. 1996). More recent work by Klein et al. indicates that such p53 mutant clones (PMCs) undergo stochastic exponential growth during periods of UV illumination (Klein et al. 2010); such a mode of growth is remarkably consistent with PMCs being derived from mutant committed progenitor (CP) cells (Clayton et al. 2007; Mascré et al. 2012) that show a stochastic cell fate tipped in favor of proliferation. Further, once UV exposure ceases, the data suggest that the proliferation and loss of p53 mutant cells become balanced so that the population of preneoplastic cells reaches a steady state. Notably, such a paradigm for the behavior of p53 mutant cells in the skin is fully compatible with the cell competition model described above-in the presence of UV-induced stress, p53 mutant CP cells have a proliferative/survival advantage more than wild-type CP cells, leading to the expansion of PMCs; on UV cessation, this competitive advantage disappears, so that the stochastic cell fate of p53 mutant CP cells is once again balanced between proliferation and loss. This interpretation is supported by a recent report describing the effect of p53 deletion on stem cell competition within the intestinal stem cell niche (Vermeulen et al. 2013)

Besides TP53, another tumor-suppressor gene commonly mutated in tumors is PTEN (Li et al. 1997; Steck et al. 1997), which negatively regulates the PI3K-Akt signaling pathway downstream from Ras. Although somatic PTEN mutations have not been reported in cutaneous SCC, germline PTEN mutations are the cause of Cowden Disease in humans, which is associated with an elevated risk of SCC (Liaw et al. 1997). Mice that are Pten-null in their epidermis develop spontaneous papillomas, many of which eventually progress to malignancy (Suzuki et al. 2003). Further, Pten ${ }^{+/-}$mice treated with the DMBA/TPA protocol have increased papilloma numbers and develop SCCs at a faster rate (Mao et al. 2004). Interestingly, most of the SCCs from these mice do not have an initiating Hras mutation; rather, these SCCs have lost their remaining copy of wild-type Pten, while the minority of SCCs that do have an Hras mutation retain their wild-type Pten. Hence, Hras activation and Pten $\mathrm{LOH}$ are mutually exclusive events in the DMBA/TPA model, which may be because of their redundant effects in activating Akt signaling. In support of this hypothesis, Pten-null SCCs have down-regulated pERK levels but similar pAkt levels compared with Hras-mutated SCCs, which suggests that Akt signaling, and not MAPK signaling, may be the critical Ras effector in this particular model of skin carcinogenesis.

\section{TUMOR-SUPPRESSOR AND NON-CELL- AUTONOMOUS EFFECTS OF NOTCH SIGNALING IN SCC DEVELOPMENT}

Notch signaling has been implicated in controlling the process of keratinocyte differentiation (Lowell et al. 2000; Rangarajan et al. 2001). In vitro, activated Notch1 in keratinocytes induces p21 expression, which leads to growth arrest, whereas in vivo, keratinocyte-specific deletion of Notch1 results in epidermal hyperplasia and deregulated expression of differentiation mark- 
ers. These observations suggest a role for Notch1 in limiting proliferation in the skin, in contrast to the situation in many other tissues where Notch signaling is involved in preventing differentiation and plays a positive oncogenic role (Jhappan et al. 1992; Zagouras et al. 1995; Capobianco et al. 1997). Indeed, loss-of-function mutations in NOTCH1 or NOTCH2 have been reported in $75 \%$ of human cutaneous SCCs (Wang et al. 2011), which indicates a tumor-suppressor function for Notch signaling in SCC development.

To investigate this, Nicholas et al. (2003) ablated Notch1 postnatally in the epidermis of mice. These mice developed spontaneous BCClike skin tumors, and were more susceptible to tumor development when subjected to the DMBA/TPA protocol. The chemically induced tumors were mostly papillomas, but also included some malignant SCCs and BCC-like tumors. The authors suggest that the increased tumor susceptibility may be caused by heightened Gli2 expression and derepressed $\beta$-catenin signaling in Notch1-deficient epidermis. In line with these observations, mice that overexpress the pan-Notch inhibitor DNMAML1 in their skin also show enhanced epidermal $\beta$-catenin signaling and develop spontaneous skin tumors, although these were histologically characterized as SCCs and not BCCs (Proweller et al. 2006).

More recently, a non-cell-autonomous tumor-suppressor function has been reported for Notch1 in the epidermis. Using mice with a chimeric pattern of Notch1 deletion in the epidermis, Demehri et al. (2009) showed that both Notch1-deleted and Notch1-expressing keratinocytes readily formed papillomas in the DMBA/TPA model, which indicates that Notch1 does not suppress tumorigenesis in a cell autonomous fashion. Rather, Notch1 loss leads to defective skin barrier formation and thus induces wound repair responses; the resulting stromal microenvironment is characterized by inflammation, dermal fibroplasia and increased angiogenesis, which the authors suggest to be responsible for promoting tumor formation in these mice. In support of this hypothesis, deletion of other Notch paralogs that also im- paired skin barrier formation similarly led to spontaneous skin tumor development.

Further evidence for a non-cell-autonomous function for Notch signaling in the epidermis comes from Ambler and Watt (2010). Here, the authors activated Notch signaling aberrantly in the epidermis, by utilizing transgenic mice with 4-hydroxy-tamoxifen (4OHT)-inducible, K14-driven expression of the Notch intracellular domain (NICD) (Ambler and Watt 2010). On the 4OHT application, these mice developed blisters at the epidermal-dermal junction, along with dermal accumulation of T lymphocytes and stromal cells. The authors showed that this phenotype was dependent on up-regulation of the Notch ligand Jag-1 in the epidermis, which is associated with a concomitant induction of Jag-1 in the underlying dermis and activated NF- $\kappa \mathrm{B}$ signaling. Hence, the authors concluded that Jag-1 is a key mediator of noncell-autonomous epidermal Notch signaling.

Finally, a non-cell-autonomous role for Notch signaling in the dermis has also been re-

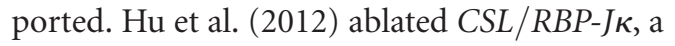
key Notch effector, specifically in murine mesenchyme, which includes the dermal fibroblasts that underlie the epidermis. These mice developed dermal atrophy and inflammation, which preceded the spontaneous appearance of multifocal SCCs. CSL-deficient dermal fibroblasts were shown to show features of cancer-associated fibroblasts, such as the expression of growth factors and matrix metalloproteases, as well as the deposition of Periostin and Tenascin Ctwo extracellular matrix proteins that have been reported to foster cancer stem cell niches (Oskarsson et al. 2011; Malanchi et al. 2012). Importantly, in human skin samples, the stroma underlying premalignant lesions also showed reduced Notch signaling; moreover, UVA exposure was shown to be capable of inducing NOTCH2 silencing by DNA methylation in human skin explants, which provides a potential mechanism for how dermal Notch signaling may be down-regulated in response to sun exposure that predisposes to SCC development.

Therefore, in the skin, Notch signaling may have both cell-autonomous and non-cellautonomous tumor-suppressor activities, the 
latter deriving from a crosstalk between the epidermis and the underlying dermis.

\section{POSITIVE AND NEGATIVE ROLES OF INFLAMMATION IN SKIN CARCINOGENESIS}

Inflammation is a common feature of the tumor microenvironment, with $25 \%$ of cancers estimated to be associated with chronic inflammation (Mantovani et al. 2008). Indeed, inflammation has been considered an "enabling characteristic" that facilitates the acquisition of cancer hallmarks, capable of nurturing nascent lesions into full-blown tumors by orchestrating the action of such players as growth and proangiogenic factors (Hanahan and Weinberg 2011). In the DMBA/TPA model, in particular, inflammation is thought to play a key role in promotion, as TPA induces the production of cytokines (such as TNF- $\alpha$ and IL- $1 \alpha$ ) and eicosanoids (such as prostaglandins) that are crucial mediators of inflammatory responses (Hursting et al. 1999).

To elucidate the role of inflammation in skin carcinogenesis, many groups again used transgenic and knockout mice in conjunction with the DMBA/TPA model. For instance, TNF- $\alpha$ is transiently but extensively induced in the epidermis on TPA treatment (Moore et al. 1999). To investigate the role of TNF- $\alpha$ in skin carcinogenesis, TNF- $\alpha^{-/-}$mice were subjected to the DMBA/TPA protocol (Moore et al. 1999; Suganuma et al. 1999). These mice showed resistance to papilloma development, and because TPA-induced keratinocyte hyperproliferation and inflammation was suppressed while malignant progression was unaffected, Moore et al. (1999) also concluded that keratinocyte-produced TNF- $\alpha$ is critical to the promotion phase but not later stages of skin carcinogenesis. More recently, the tumor resistance of $T N F-\alpha^{-/-}$ mice has also been partly attributed to a defect in B cells (Schioppa et al. 2011). In the absence of TNF- $\alpha$ signaling, mice have lower levels of Il10 -producing B regulatory cells and this is associated with an increase in IFN- $\gamma$-producing, antitumor $\mathrm{CD}^{+} \mathrm{T}$ cells in the skin.
Apart from TNF- $\alpha$, Stat 3 is another key factor implicated in cancer-related inflammation (Mantovani et al. 2008). It is constitutively activated in both tumor and immune cells in the tumor microenvironment, and is thought to have a central role in mediating the suppression of antitumor immune responses (Yu et al. 2007). Accordingly, skin tumor promoters have been shown to activate Stat 3 expression in the skin (Chan et al. 2004a), and epidermis-specific ablation of Stat3 abrogates tumor formation in the DMBA/TPA model (Chan et al. 2004b). Also in line with a protumor role for inflammation, when mice lacking $C O X-1$ or $C O X-2$ (the key enzymes catalyzing the first committed step in prostaglandin synthesis) were treated with the DMBA/TPA protocol, tumor development was profoundly inhibited (Tiano et al. 2002). These mice showed suppressed prostaglandin production in TPA-treated skin and in papillomas, and tumor growth inhibition was attributed to enhanced keratinocyte differentiation.

A positive role for inflammation was also shown using transgenic mice that overexpress activated Mek1 in the suprabasal layer of the IFE (the InvEE mice described earlier). These animals develop epidermal hyperproliferation and skin inflammation (Hobbs et al. 2004), and papillomas form after wounding (Arwert et al. 2010). The authors show that the terminally differentiating cells expressing activated Mek1 contribute to tumorigenesis by stimulating neighboring, transgene-negative basal cells to proliferate, which then become incorporated into the developing tumor mass. Tumorigenesis is dependent on IL-1 $\alpha$ production and infiltrating immune cells such as $\gamma \delta$-T cells and macrophages. This study shows that besides reacquiring the ability to divide, differentiating cells can also contribute to tumor development by providing non-cell-autonomous signals to proliferative cells, in this case, IL- $1 \alpha$, which fosters an inflammatory microenvironment.

However, not all proinflammatory factors have a tumor-promoting effect. For instance, $K 14 / I L-1 \alpha$ transgenic mice that overexpress IL- $1 \alpha$ in the basal layer of their epidermis are known to develop spontaneous skin inflammation, characterized by the expression of pro- 
inflammatory cytokines and chemokines (Groves et al. 1995). However, when these mice were subjected to the DMBA/TPA protocol, tumor formation was, surprisingly, strongly inhibited (Murphy et al. 2013). Similarly, mice selectively bred to have maximal acute inflammatory responsiveness were shown to be resistant to DMBA/TPA-induced skin carcinogenesis (Biozzi et al. 1998). Additionally, anti-inflammatory agents were reported to have contradictory effects on mouse skin tumor promotion (Viaje et al. 1977).

Further support for a tumor-inhibiting role for inflammation came from analysis of the effects of germline polymorphisms on gene expression networks in skins from a genetically heterogeneous population of mice (Quigley et al. 2009). Gene expression networks associated with tumor susceptibility showed higher expression of the inflammation antagonists $\mathrm{Il}$ $15 f$ and $I l-16 f$ and lower expression of proinflammatory Pde4b, consistent with an antitumor effect for inflammation in this context.

As illustrated by the above studies, many of the cytokines that mediate inflammatory responses in the skin are produced by the epithelial cells themselves and not solely by skinresident or infiltrating immune cells. These epithelial-derived, secreted molecules and other molecules displayed on the surface of epithelial cells, collectively termed the "epimmunome" (Swamy et al. 2010), can play a key role in instructing immune cells and consequently impinge on immunocompetence and tumor immunosurveillance. For instance, the major histocompatibility complex class I protein Rae-1 is expressed on skin epithelial cells and engages the activating receptor NKG2D expressed on a variety of immune cell types, such as Natural Killer cells and $\mathrm{CD} 8^{+} \mathrm{T}$ cells. Rae- 1 expression in the skin is known to be upregulated within $24 \mathrm{~h}$ of carcinogen treatment, and is also sustained throughout papilloma and carcinoma development (Girardi et al. 2001). When Rae- 1 is acutely induced in the epidermis of transgenic mice, the two resident immune cell populations in the skin, the dendritic epidermal $\mathrm{T}$ cells (DETCs) and antigen-presenting Langerhans cells, undergo rapid, simultaneous re- organization, followed soon after by the infiltration of T cells (Strid et al. 2008). The authors of this study also showed that whereas DETCs are tumor-inhibiting, Langerhans cells are tumorpromoting, which thus suggests a potential role for Rae- 1 in the early stages of a complex, multidimensional tumor immunosurveillance program.

In summary, the role of inflammation in skin carcinogenesis is a highly complex one, with possibly different consequences depending on the balance among individual members of the immune cell and cytokine network present in the tumor. Another factor that plays into this dynamic is the category-whether class A or B-of skin carcinomas involved. Mice treated with a modified DMBA/TPA protocol in which the duration of TPA treatment was restricted to $5-10 \mathrm{wk}$, rather than the usual $20 \mathrm{wk}$, showed the highest relative proportion of Class B (spindle) carcinomas (Wong et al. 2013). This suggests that class $\mathrm{B}$ carcinomas arise through a pathway that is less dependent on TPA-induced inflammation, whereas class A squamous papillomas and carcinomas are highly dependent on this inflammatory stimulus. Previous data are also compatible with this notion of an alternative route to tumor formation that has different requirements for inflammation (Fig. 2). Although $K 14 / I L-1 \alpha$ transgenic mice, as described above, are resistant to tumor development via the classical route when treated with the DMBA/TPA protocol, they nevertheless show increased susceptibility to de novo carcinoma formation when subjected to the complete carcinogenesis protocol (Groves et al. $1995)$. On the other hand, K14-PKC- $\varepsilon$ transgenic mice that overexpress the $P K C$ isoform $P K C-\varepsilon$ in basal keratinocytes develop spontaneous skin inflammation; when treated with the DMBA/ TPA protocol, these mice developed, on average, less than one papilloma per mouse via the classical route but nevertheless showed increased de novo carcinoma formation (Reddig et al. 2000).

Finally, to highlight the dynamic nature of the role of inflammation in skin carcinogenesis, two recent studies looked at TSLP-mediated inflammation in the skin (Demehri et al. 2012; Piazza et al. 2012). Ablation of both Notch1 and 
Notch2 or RBP-J $\kappa$ alone in the mouse skin led to a chronic inflammatory condition caused by heightened TSLP expression by keratinocytes. When TSLP receptor components were also genetically deleted in these mice, spontaneous skin tumors arose. The authors showed that this was caused by the depletion of antitumor T cells in the inflammatory infiltrate on loss of TSLP signaling; Piazza et al. (2012) also showed in their model that in place of $\mathrm{T}$ cells, protumor myeloid cells accumulated and supplied Wnt ligands, which were necessary for tumor development in this context.

The above examples illustrate how loss of signaling of one cytokine can induce a switch in the inflammatory profile from one that is antitumor to one that is protumor. In the future, studying how to tip the balance in favor of "good" inflammation in tumors may be a fruitful avenue for developing treatments for SCC in the clinic.

\section{CONCLUDING REMARKS}

When considering the vast literature on the DMBA/TPA model of SCC development, it is worthwhile bearing in mind a couple of caveats. First, many studies use constitutive, whole-body knockout mice, in which any phenotypes observed can be caused by developmental effects or non-cell-autonomous effects from gene deletion in tissues other than the skin. A good example of the latter phenomenon is how loss of Notch signaling in the dermis is capable of fostering skin tumor formation (Hu et al. 2012). In principle, the development of inducible, conditional knockout mice addresses many of these concerns, but one should still be wary of issues of promoter leakiness and recombination efficiency. Second, many studies look only at the early stages of carcinogenesis. Relatively few look at the clinically relevant stages of tumor development, that is, progression to malignancy and metastasis.

In conclusion, the DMBA/TPA model remains very much relevant to current research into the biology and genetics of SCC. Although RAS mutations are found in only $5 \%-10 \%$ of human SCCs, the prevalence of SCC develop- ment in Caucasians is very high, resulting in many thousands of patients yearly with HRAS or KRAS mutations, including the common mutations found in the DMBA/TPA mouse model. Because there are presently no treatments available generally for RAS mutant tumors in any tissue, this mouse model has the potential to provide crucial directions for the future development of novel drug targets, chemoprevention strategies and clinical treatments.

\section{ACKNOWLEDGMENTS}

We thank Minh D. To, Jonas Sjolund, and Ihn Young Song for critical comments and suggestions. A.B. acknowledges support from the Mouse Models of Human Cancers Consortium (MMHCC) UO1 Grant CA084244 and the Barbara Bass Bakar Chair of Cancer Genetics. P.Y.H. is supported by the NSS-PhD Scholarship from the Agency for Science, Technology and Research (A*STAR) and the California Institute of Regenerative Medicine (CIRM) (Grant No. TG2-01153).

\section{REFERENCES}

Agrawal N, Frederick MJ, Pickering CR, Bettegowda C, Chang K, Li RJ, Fakhry C, Xie T-X, Zhang J, Wang J, et al. 2011. Exome sequencing of head and neck squamous cell carcinoma reveals inactivating mutations in NOTCH1. Science 333: 1154-1157.

Alam M, Ratner D. 2001. Cutaneous squamous-cell carcinoma. NEJM 344: 975-983.

Aldaz CM, Trono D, Larcher F, Slaga TJ, Conti CJ. 1989. Sequential trisomization of chromosomes 6 and 7 in mouse skin premalignant lesions. Mol Carcinog 2: 22-26.

Ambler CA, Watt FM. 2010. Adult epidermal Notch activity induces dermal accumulation of T cells and neural crest derivatives through upregulation of jagged 1. Development 137: 3569-3579.

Argyris TS. 1985. Promotion of epidermal carcinogenesis by repeated damage to mouse skin. Am J Ind Med 8: 329-337.

Arnold I, Watt FM. 2001. c-Myc activation in transgenic mouse epidermis results in mobilization of stem cells and differentiation of their progeny. Curr Biol 11: 558568.

Arwert EN, Lal R, Quist S, Rosewell I, van Rooijen N, Watt FM. 2010. Tumor formation initiated by nondividing epidermal cells via an inflammatory infiltrate. Proc Natl Acad Sci 107: 19903-19908.

Bai Y, Edamatsu H, Maeda S, Saito H, Suzuki N, Satoh T, Kataoka T. 2004. Crucial role of phospholipase $\mathrm{C} \varepsilon$ in 
P.Y. Huang and A. Balmain

chemical carcinogen-induced skin tumor development. Cancer Res 64: 8808-8810.

Bailleul B, Surani MA, White S, Barton SC, Brown K, Blessing M, Jorcano J, Balmain A. 1990. Skin hyperkeratosis and papilloma formation in transgenic mice expressing a ras oncogene from a suprabasal keratin promoter. Cell 62: 697-708.

Balmain A, Pragnell I. 1983. Mouse skin carcinomas induced in vivo by chemical carcinogens have a transforming Harvey-ras oncogene. Nature 303: 72-74.

Balmain A, Ramsden M, Bowden G, Smith J. 1984. Activation of the mouse cellular Harvey-ras gene in chemically induced benign skin papillomas. Nature 307: 658-660.

Benitah SA, Frye M, Glogauer M, Watt FM. 2005. Stem cell depletion through epidermal deletion of Racl. Science 309: 933-935.

Berenblum I, Shubik P. 1949. The persistence of latent tumour cells induced in the mouse's skin by a single application of 9:10-dimethyl-1:2-benzanthracene. Br J Cancer 3: $384-386$.

Berg RJ, van Kranen HJ, Rebel HG, de Vries A, van Vloten WA, van Kreijl CF, van der Leun JC, de Gruijl FR. 1996. Early p53 alterations in mouse skin carcinogenesis by UVB radiation: Immunohistochemical detection of mutant p53 protein in clusters of preneoplastic epidermal cells. Proc Natl Acad Sci 93: 274-278.

Biozzi G, Ribeiro OG, Saran A, Araujo ML, Maria DA, De Franco M, Cabrera WK, Sant'anna OA, Massa S, Covelli $\mathrm{V}$, et al. 1998. Effect of genetic modification of acute inflammatory responsiveness on tumorigenesis in the mouse. Carcinogenesis 19: 337-346.

Bondar T, Medzhitov R. 2010. p53-mediated hematopoietic stem and progenitor cell competition. Cell Stem Cell 6: $309-322$.

Bourcier C, Jacquel A, Hess J, Peyrottes I, Angel P, Hofman P, Auberger P, Pouysségur J, Pagès G. 2006. P44 mitogenactivated protein kinase (extracellular signal-regulated kinase 1)-dependent signaling contributes to epithelial skin carcinogenesis. Cancer Res 66: 2700-2707.

Boutwell RK, Verma AK, Ashendel CL, Astrup AE. 1982. Mouse skin: A useful model system for studying the mechanism of chemical carcinogenesis. Carcinog Compr Surv 7: 1-12.

Bremner F, Balmain A. 1990. Genetic changes in skin tumor progression: Correlation between presence of a mutant ras gene and loss of heterozygosity on mouse chromosome 7. Cell 61: 407-417.

Brown K, Quintanilla M, Ramsden M, Kerr IB, Young S, Balmain A. 1986. v-ras genes from Harvey and BALB murine sarcoma viruses can act as initiators of two-stage mouse skin carcinogenesis. Cell 46: 447-456.

Brown K, Buchmann A, Balmain A. 1990. Carcinogen-induced mutations in the mouse c-Ha-ras gene provide evidence of multiple pathways for tumor progression. Proc Natl Acad Sci 87: 538-542.

Brown K, Strathdee D, Bryson S, Lambie W, Balmain A. 1998. The malignant capacity of skin tumours induced by expression of a mutant $\mathrm{H}$-ras transgene depends on the cell type targeted. Curr Biol 8: 516-524.

Buchmann A, Ruggeri B, Klein-Szanto A, Balmain A. 1991. Progression of squamous carcinoma cells to spindle car- cinomas of mouse skin is associated with an imbalance of H-ras alleles on chromosome 7. Cancer Res 51: 40974101.

Burns P, Kemp C, Gannon J, Lane D, Bremner R, Balmain A. 1991. Loss of heterozygosity and mutational alterations of the $p 53$ gene in skin tumours of interspecific hybrid mice. Oncogene 6: 2363-2369.

Byrne C, Fuchs E. 1993. Probing keratinocyte and differentiation specificity of the human $\mathrm{K} 5$ promoter in vitro and in transgenic mice. Mol Cell Biol 13: 3176-3190.

Capobianco A, Zagouras P, Blaumueller C, ArtavanisTsakonas S, Bishop J. 1997. Neoplastic transformation by truncated alleles of human NOTCH1/TAN1 and NOTCH2. Mol Cell Biol 17: 6265-6273.

Castagna M, Takai Y, Kaibuchi K, Sano K, Kikkawa U, Nishizuka Y. 1982. Direct activation of calcium-activated phospholipid-dependent protein kinase by tumor-promoting phorbol esters. J Biol Chem 257: 7847-7851.

Cataisson C, Ohman R, Patel G, Pearson A, Tsien M, Jay S, Wright L, Hennings H, Yuspa SH. 2009. Inducible cutaneous inflammation reveals a protumorigenic role for keratinocyte CXCR2 in skin carcinogenesis. Cancer Res 69: 319-328.

Caulin C, Nguyen T, Lang GA, Goepfert TM, Brinkley BR, Cai W, Lozano G, Roop DR. 2007. An inducible mouse model for skin cancer reveals distinct roles for gain- and loss-of-function p53 mutations. J Clin Invest 117: 1893 1901.

Chan KS, Carbajal S, Kiguchi K, Clifford J, Sano S, DiGiovanni J. 2004a. Epidermal growth factor receptor-mediated activation of Stat 3 during multistage skin carcinogenesis. Cancer Res 64: 2382-2389.

Chan KS, Sano S, Kiguchi K, Anders J, Komazawa N, Takeda J, DiGiovanni J. 2004b. Disruption of Stat3 reveals a critical role in both the initiation and the promotion stages of epithelial carcinogenesis. J Clin Invest 114: 720-728.

Chen N, Nomura M, She Q, Ma W, Bode AM, Wang L, Flavell RA, Dong Z. 2001. Suppression of skin tumorigenesis in c-Jun NH2-terminal kinase-2-deficient mice. Cancer Res 61: 3908-3912.

Chen J, Li Y, Yu T-S, McKay RM, Burns DK, Kernie SG, Parada LF. 2012. A restricted cell population propagates glioblastoma growth after chemotherapy. Nature 488: $522-526$.

Chida K, Hara T, Hirai T, Konishi C, Nakamura K, Nakao K, Aiba A, Katsuki M, Kuroki T. 2003. Disruption of protein kinase $\mathrm{C} \eta$ results in impairment of wound healing and enhancement of tumor formation in mouse skin carcinogenesis. Cancer Res 63: 2404-2408.

Chow HY, Jubb AM, Koch JN, Jaffer ZM, Stepanova D, Campbell DA, Duron SG, O'Farrell M, Cai KQ, KleinSzanto AJP, et al. 2012. p21-activated kinase 1 is required for efficient tumor formation and progression in a Rasmediated skin cancer model. Cancer Res 72: 5966-5975.

Chrostek A, Wu X, Quondamatteo F, Hu R, Sanecka A Niemann C, Langbein L, Haase I, Brakebusch C. 2006. Rac1 is crucial for hair follicle integrity but is not essential for maintenance of the epidermis. Mol Cell Biol 26: 6957-6970.

Cicalese A, Bonizzi G, Pasi CE, Faretta M, Ronzoni S, Giulini B, Brisken C, Minucci S, Di Fiore PP, Pelicci PG. 2009 The tumor suppressor p53 regulates polarity of self-re- 
newing divisions in mammary stem cells. Cell 138: 10831095.

Clayton E, Doupé DP, Klein AM, Winton DJ, Simons BD, Jones PH. 2007. A single type of progenitor cell maintains normal epidermis. Nature 446: 185-189.

Dejosez M, Ura H, Brandt VL, Zwaka TP. 2013. Safeguards for cell cooperation in mouse embryogenesis shown by genome-wide cheater screen. Science 341: 1511-1514.

Demehri S, Turkoz A, Kopan R. 2009. Epidermal Notch1 loss promotes skin tumorigenesis by impacting the stromal microenvironment. Cancer Cell 16: 55-66.

Demehri S, Turkoz A, Manivasagam S, Yockey LJ, Turkoz M, Kopan R. 2012. Elevated epidermal thymic stromal lymphopoietin levels establish an antitumor environment in the skin. Cancer Cell 22: 494-505.

De Ruiter N, Wolthuis R, van Dam H, Burgering B, Bos J. 2000. Ras-dependent regulation of c-Jun phosphorylation is mediated by the Ral guanine nucleotide exchange factor-Ral pathway. Mol Cell Biol 20: 8480-8488.

Dominey AM, Wang X, King LE, Nanney LB, Gagne TA, Sellheyer K, Bundman DS, Longley MA, Rothnagel JA, Greenhalgh DA, et al. 1993. Targeted overexpression of transforming growth factor $\alpha$ in the epidermis of transgenic mice elicits hyperplasia, hyperkeratosis, and spontaneous, squamous papillomas. Cell Growth Differ 4: 1071-1082.

Driessens G, Beck B, Caauwe A, Simons BD, Blanpain C. 2012. Defining the mode of tumour growth by clonal analysis. Nature 1-5.

Durinck S, Ho C, Wang NJ, Liao W, Jakkula LR, Collisson EA, Pons J, Chan S-W, Lam ET, Chu C, et al. 2011. Temporal dissection of tumorigenesis in primary cancers. Cancer Discov 1: 137-143.

Ehrenreiter K, Piazzolla D, Velamoor V, Sobczak I, Small JV, Takeda J, Leung T, Baccarini M. 2005. Raf-1 regulates $\rho$ signaling and cell migration. J Cell Biol 168: 955-964.

Ehrenreiter K, Kern F, Velamoor V, Meissl K, Galabova-Kovacs $G$, Sibilia M, Baccarini M. 2009. Raf-1 addiction in Ras-induced skin carcinogenesis. Cancer Cell 16: 149160.

Feith DJ, Bol DK, Carboni JM, Protein M, Kinase K, Lynch MJ, Sass-Kuhn S, Shoop PL, Shantz LM. 2005. Induction of ornithine decarboxylase activity is a necessary step for mitogen-activated protein kinase kinase-induced skin tumorigenesis. Cancer Res 65: 572-578.

Feldser DM, Kostova KK, Winslow MM, Taylor SE, Cashman C, Whittaker CA, Sanchez-Rivera FJ, Resnick R, Bronson R, Hemann MT, et al. 2010. Stage-specific sensitivity to p53 restoration during lung cancer progression. Nature 468: 572-575.

Fournier A, Murray A. 1987. Application of phorbol ester to mouse skin causes a rapid and sustained loss of protein kinase C. Nature 330: 767-769.

Fuchs E, Esteves R, Coulombe P. 1992. Transgenic mice expressing a mutant keratin 10 gene reveal the likely genetic basis for epidermolytic hyperkeratosis. Proc Natl Acad Sci 89: 6906-6910.

Gerdes MJ, Myakishev M, Frost NA, Rishi V, Moitra J, Acharya A, Levy MR, Park S, Glick A, Yuspa SH, et al 2006. Activator protein-1 activity regulates epithelial tumor cell identity. Cancer Res 66: 7578-7588.
Girardi M, Oppenheim DE, Steele CR, Lewis JM, Glusac E, Filler R, Hobby P, Sutton B, Tigelaar RE, Hayday AC. 2001. Regulation of cutaneous malignancy by $\gamma \delta$-T cells. Science 294: 605-609.

Gomez C, Chua W, Miremadi A, Quist S, Headon DJ, Watt FM. 2013. The interfollicular epidermis of adult mouse tail comprises two distinct cell lineages that are differentially regulated by Wnt, Edaradd, and Lrig1. Stem Cell Reports 1: 19-27.

González-García A, Pritchard CA, Paterson HF, Mavria G, Stamp G, Marshall CJ. 2005. RalGDS is required for tumor formation in a model of skin carcinogenesis. Cancer Cell 7: 219-226.

Gonzalez-Suarez E, Jacob AP, Jones J, Miller R, RoudierMeyer MP, Erwert R, Pinkas J, Branstetter D, Dougall WC. 2010. RANK ligand mediates progestin-induced mammary epithelial proliferation and carcinogenesis. Nature 468: 103-107.

Goudie DR, D'Alessandro M, Merriman B, Lee H, Szeverényi I, Avery S, O'Connor BD, Nelson SF, Coats SE, Stewart A, et al. 2011. Multiple self-healing squamous epithelioma is caused by a disease-specific spectrum of mutations in TGFBR1. Nat Genet 43: 365-369.

Greenhalgh D, Rothnagel J, Quintanilla M, Orengo C, Gagne T, Bundman D, Longley M, Roop D. 1993. Induction of epidermal hyperplasia, hyperkeratosis, and papillomas in transgenic mice by a targeted v-Ha-ras oncogene. Mol Carcinog 7: 99-110.

Grossbart TA, Lew RA. 1996. Prevention and early detection strategies for melanoma and skin cancer. Current status. Arch Dermatol 132: 436-443.

Groves RW, Mizutani H, Kieffer JD, Kupper TS. 1995. Inflammatory skin disease in transgenic mice that express high levels of interleukin $1 \alpha$ in basal epidermis. Proc Natl Acad Sci 92: 11874-11878.

Gupta PB, Chaffer CL, Weinberg RA. 2009. Cancer stem cells: Mirage or reality? Nat Med 15: 1010-1012.

Hanahan D, Weinberg RA. 2011. Hallmarks of cancer: The next generation. Cell 144: 646-674.

Hanahan D, Wagner EF, Palmiter RD. 2007. The origins of oncomice: A history of the first transgenic mice genetically engineered to develop cancer. Genes Dev 21: 2258 2270.

Hansen LA, Monteiro-Riviere NA, Smart RC. 1990. Differential down-regulation of epidermal protein kinase $\mathrm{C}$ by 12-O-tetradecanoylphorbol-13-acetate and diacylglycerol: Association with epidermal hyperplasia and tumor promotion. Cancer Res 50: 5740-5745.

Hennings H, Glick AB, Lowry DT, Krsmanovic LS, Sly LM, Yuspa SH. 1993. FVB/N mice: An inbred strain sensitive to the chemical induction of squamous cell carcinomas in the skin. Carcinogenesis 14: 2353-2358.

Hobbs RM, Silva-Vargas V, Groves R, Watt FM. 2004. Expression of activated MEK1 in differentiating epidermal cells is sufficient to generate hyperproliferative and inflammatory skin lesions. J Invest Dermatol 123: 503-515.

Honeycutt KA, Waikel RL, Koster MI, Wang X-J, Roop DR. 2010. The effect of c-myc on stem cell fate influences skin tumor phenotype. Mol Carcinog 49: 315-319.

Hordijk P, ten Klooster J, van der Kammen R, Michiels F, Oomen L, Collard J. 1997. Inhibition of invasion of ep- 
P.Y. Huang and A. Balmain

ithelial cells by Tiam1-Rac signalling. Science 278: 14641466.

Hu B, Castillo E, Harewood L, Ostano P, Reymond A, Dummer R, Raffoul W, Hoetzenecker W, Hofbauer GFL, Dotto GP. 2012. Multifocal epithelial tumors and field cancerization from loss of mesenchymal CSL signaling. Cell 149: 1207-1220.

Hursting SD, Slaga TJ, Fischer SM, DiGiovanni J, Phang JM. 1999. Mechanism-based cancer prevention approaches: Targets, examples, and the use of transgenic mice. J Natl Cancer Inst 91: 215-225.

Jacks T. 1996. Tumor suppressor gene mutations in mice. Annu Rev Genet 30: 603-636.

Jackson EL, Willis N, Mercer K, Bronson RT, Crowley D, Montoya R, Jacks T, Tuveson DA. 2001. Analysis of lung tumor initiation and progression using conditional expression of oncogenic K-ras. Genes Dev 15: 3243-3248.

Jaks V, Kasper M, Toftgård R. 2010. The hair follicle—A stem cell zoo. Exp Cell Res 316: 1422-1428.

Jensen KB, Collins CA, Nascimento E, Tan DW, Frye M, Itami S, Watt FM. 2009. Lrig1 expression defines a distinct multipotent stem cell population in mammalian epidermis. Cell Stem Cell 4: 427-439.

Jhappan C, Gallahan D, Stahle C, Chu E, Smith G, Merlino G, Callahan R. 1992. Expression of an activated Notchrelated int-3 transgene interferes with cell differentiation and induces neoplastic transformation in mammary and salivary glands. Genes Dev 6: 345-355.

Jonason A, Kunala S, Price G, Restifo R, Spinelli H, Persing J Leffell D, Tarone R, Brash D. 1996. Frequent clones of p53-mutated keratinocytes in normal human skin. Proc Natl Acad Sci 93: 14025-14029.

Junttila MR, Karnezis AN, Garcia D, Madriles F, Kortlever RM, Rostker F, Brown Swigart L, Pham DM, Seo Y, Evan GI, et al. 2010. Selective activation of p53-mediated tumour suppression in high-grade tumours. Nature 468: 567-571.

Kang HC, Quigley D, Kim I-J, Wakabayashi Y, FergusonSmith M, D'Alessandro M, Lane EB, Akhurst RJ, Goudie DR, Balmain A. 2013. Multiple self-healing squamous epithelioma (MSSE): Rare variants in an adjacent region of chromosome 9q22.3 to known TGFBR1 mutations suggest a digenic or multilocus etiology. J Invest Dermatol 133: 1907-1910.

Keely P, Westwick J, Whitehead I, Der C, Parise L. 1997. Cdc42 and Rac1 induce integrin-mediated cell motility and invasiveness through PI3K. Nature 390: 632-636.

Kemp CJ, Donehower LA, Bradley A, Balmain A. 1993. Reduction of $p 53$ gene dosage does not increase initiation or promotion but enhances malignant progression of chemically induced skin tumors. Cell 74: 813-22.

Khavari P. 2006. Modelling cancer in human skin tissue. Nat Rev Cancer 6: 270-280.

Klein AM, Brash DE, Jones PH, Simons BD. 2010. Stochastic fate of p53-mutant epidermal progenitor cells is tilted toward proliferation by UVB during preneoplasia. Proc Natl Acad Sci 107: 270-275.

Klein-Szanto APJ, Larcher F, Bonfil RD, Conti CJ. 1989. Multistage chemical carcinogenesis protocols produce spindle cell carcinomas of the mouse skin. Carcinogenesis 10: $2169-2172$.
Kops G, de Ruiter N, De Vries-Smits A, Powell D, Bos J, Burgering B. 1999. Direct control of the Forkhead transcription factor AFX by protein kinase B. Nature 398: 630-634.

Kumpf S, Mihlan M, Goginashvili A, Grandl G, Gehart H, Godel A, Schmidt J, Müller J, Bezzi M, Ittner A, et al. 2012. Hairless promotes PPAR $\gamma$ expression and is required for white adipogenesis. EMBO Rep 13: $1012-$ 1020.

Lapidot T, Sirard C, Vormoor J, Mrudoch B, Hoang T, Caceres-Cortes J, Minden M, Paterson B, Caligiuri M, Dick J. 1994. A cell initiating human acute myeloid leukaemia after transplantation into SCID mice. Nature 367: 645648.

Lapouge G, Youssef KK, Vokaer B, Achouri Y, Michaux C, Sotiropoulou PA, Blanpain C. 2011. Identifying the cellular origin of squamous skin tumors. Proc Natl Acad Sci 108: $7431-7436$.

Lapouge G, Beck B, Nassar D, Dubois C, Dekoninck S, Blanpain C. 2012. Skin squamous cell carcinoma propagating cells increase with tumour progression and invasiveness. EMBO J 31: 4563-4575.

Li J, Yen C, Liaw D, Podsypanina K, Bose S, Wang S, Puc J, Miliaresis C, Rodgers L, McCombie R, et al. 1997. PTEN, a putative protein tyrosine phosphatase gene mutated in human brain, breast, and prostate cancer. Science 275: 1943-1947.

Li S, Park H, Trempus CS, Gordon D, Liu Y, Cotsarelis G, Morris RJ. 2012. A keratin 15 containing stem cell population from the hair follicle contributes to squamous papilloma development in the mouse. Mol Carcinog 52: 751-759.

Liaw D, Marsh D, Li J, Dahia P, Wang S, Zheng Z, Bose S, Call K, Tsou H, Peacocke M, et al. 1997. Germline mutations of the PTEN gene in Cowden disease, an inherited breast and thyroid cancer syndrome. Nat Genet 16: 64-67.

Loehrke H, Schweizer J, Dederer E, Hesse B, Rosenkranz G, Goerttler K. 1983. On the persistence of tumor initiation in two-stage carcinogenesis on mouse skin. Carcinogenesis 4: 771-775.

Lowell S, Jones P, Le Roux I, Dunne J, Watt FM. 2000. Stimulation of human epidermal differentiation by $\delta$-notch signalling at the boundaries of stem-cell clusters. Curr Biol 10: 491-500.

Malanchi I, Santamaria-Martínez A, Susanto E, Peng H, Lehr H-A, Delaloye J-F, Huelsken J. 2012. Interactions between cancer stem cells and their niche govern metastatic colonization. Nature 481: 85-89.

Malliri A, van der Kammen R, Clark K, van der Valk M, Michiels F, Collard JG. 2002. Mice deficient in the Rac activator Tiaml are resistant to Ras-induced skin tumours. Nature 417: 867-871.

Mantovani A, Allavena P, Sica A, Balkwill F. 2008. Cancerrelated inflammation. Nature 454: 436-444.

Mao J-H, To MD, Perez-Losada J, Wu D, Del Rosario R, Balmain A. 2004. Mutually exclusive mutations of the Pten and ras pathways in skin tumor progression. Genes Dev 18: $1800-1805$.

Mascré G, Dekoninck S, Drogat B, Youssef KK, Brohée S, Sotiropoulou PA, Simons BD, Blanpain C. 2012. Distinct contribution of stem and progenitor cells to epidermal maintenance. Nature 489: 257-262. 
Mauerer A, Herschberger E, Dietmaier W, Landthaler M, Hafner C. 2011. Low incidence of EGFR and HRAS mutations in cutaneous squamous cell carcinomas of a German cohort. Exp Dermatol 20: 848-850.

Meletis K, Wirta V, Hede S-M, Nistér M, Lundeberg J, Frisén J. 2006. P53 suppresses the self-renewal of adult neural stem cells. Development 133: 363-369.

Moore R, Owens D, Stamp G, Arnott C, Burke F, East N, Holdsworth H, Turner L, Rollins B, Pasparakis M, et al. 1999. Mice deficient in tumor necrosis factor- $\alpha$ are resistant to skin carcinogenesis. Nat Med 5: 828-831.

Morata G, Ripoli P. 1975. Minutes: Mutants of Drosophila cell division autonomously affecting cell division rate. Dev Biol 42: 211-221.

Morris RJ, Tryson KA, Wu KQ. 2000. Evidence that the epidermal targets of carcinogen action are found in the interfollicular epidermis or infundibulum as well as in the hair follicles. Cancer Res 60: 226-229.

Moskalenko S, Henry D, Rosse C, Mirey G, Camonis J, White M. 2002. The exocyst is a Ral effector complex. Nat Cell Biol 4: 66-72.

Murphy J, Morales RE, Scott J, Kupper TS. 2013. IL- $1 \alpha$, innate immunity, and skin carcinogenesis: The effect of constitutive expression of IL- $1 \alpha$ in epidermis on chemical carcinogenesis. J Immunol 170: 5697-5703.

Nakashima S, Morinaka K, Koyama S, Ikeda M, Kishida M, Okawa K, Iwamatsu A, Kishida S, Kikuchi A. 1999. Small $\mathrm{G}$ protein $\mathrm{Ral}$ and its downstream molecules regulate endocytosis of EGF and insulin receptors. EMBO J 18: 3629-3642.

Nicolas M, Wolfer A, Raj K, Kummer JA, Mill P, van Noort M, Hui C, Clevers H, Dotto GP, Radtke F. 2003. Notch1 functions as a tumor suppressor in mouse skin. Nat Genet 33: $416-421$.

Oft M, Akhurst RJ, Balmain A. 2002. Metastasis is driven by sequential elevation of H-ras and Smad2 levels. Nat Cell Biol 4: 487-494.

Olson M, Ashworth A, Hall A. 1995. An essential role for $\rho$, Rac, and Cdc42 GTPases in cell cycle progression through G1. Science 269: 1270-1272.

Olson M, Paterson H, Marshall C. 1998. Signals from Ras and $\rho$ GTPases interact to regulate expression of p21Waf1/Cip1. Nature 394: 295-299.

Oskarsson T, Acharyya S, Zhang XH, Vanharanta S, Tavazoie SF, Morris PG, Downey RJ, Manova-Todorova K, Brogi E, Massagué J. 2011. Breast cancer cells produce tenascin C as a metastatic niche component to colonize the lungs. Nat Med 17: 867-874.

Page ME, Lombard P, Ng F, Göttgens B, Jensen KB. 2013. The epidermis comprises autonomous compartments maintained by distinct stem cell populations. Cell Stem Cell 13: 471-482.

Palmiter RD, Brinster RL. 1986. Germ-line transformation of mice. Annu Rev Genet 20: 465-499.

Parma P, Radi O, Vidal V, Chaboissier MC, Dellambra E, Valentini S, Guerra L, Schedl A, Camerino G. 2006. Rspondin 1 is essential in sex determination, skin differentiation and malignancy. Nat Genet 38: 1304-1309.

Perez-Losada J, Balmain A. 2003. Stem-cell hierarchy in skin cancer. Nat Rev Cancer 3: 434-443.
Piazza M, Nowell C, Koch U, Durham A, Radtke F. 2012. Loss of cutaneous TSLP-dependent immune responses skews the balance of inflammation from tumor protective to tumor promoting. Cancer Cell 22: 479-493.

Pott P. 1775. Cancer scroti. In Chirurgical observations, pp. 63-68. Hawes, Clarke, Collins, London.

Potten C. 1981. Cell replacement in epidermis (keratopoiesis) via discrete units of proliferation. Int Rev Cytol 69: 271-318.

Potten C, Wichmann H, Loeffler M, Dobek K, Major D. 1982. Evidence for discrete cell kinetic subpopulations in mouse epidermis based on mathematical analysis. Cell Tissue Kinet 15: 305-329.

Proweller A, Tu L, Lepore JJ, Cheng L, Lu MM, Seykora J, Millar SE, Pear WS, Parmacek MS. 2006. Impaired notch signaling promotes de novo squamous cell carcinoma formation. Cancer Res 66: 7438-7444.

Quigley DA, To MD, Pérez-Losada J, Pelorosso FG, Mao J-H, Nagase H, Ginzinger DG, Balmain A. 2009. Genetic architecture of mouse skin inflammation and tumour susceptibility. Nature 458: 505-508.

Quintanilla M, Brown K, Ramsden M, Balmain A. 1986. Carcinogen-specific mutation and amplification of Ha-ras during mouse skin carcinogenesis. Nature 322: $78-80$.

Rangarajan A, Talora C, Okuyama R, Nicolas M, Mammucari C, Oh H, Aster JC, Krishna S, Metzger D, Chambon P, et al. 2001. Notch signaling is a direct determinant of keratinocyte growth arrest and entry into differentiation. EMBO J 20: 3427-3436.

Reddig PJ, Dreckschmidt NE, Ahrens H, Simsiman R, Tseng CP, Zou J, Oberley TD, Verma AK. 1999. Transgenic mice overexpressing protein kinase $C \delta$ in the epidermis are resistant to skin tumor promotion by $12-\mathrm{O}$-tetradecanoylphorbol-13-acetate. Cancer Res 59: 5710-5718.

Reddig PJ, Dreckschmidt NE, Zou J, Bourguignon SE, Oberley TD, Verma AK. 2000. Transgenic mice overexpressing protein kinase $\mathrm{C}$ epsilon in their epidermis exhibit reduced papilloma burden but enhanced carcinoma formation after tumor promotion. Cancer Res 60: 595-602.

Ren Z, Hedrum A, Pontén F, Nistér M, Ahmadian A, Lundeberg J, Uhlén M, Pontén J. 1996. Human epidermal cancer and accompanying precursors have identical p53 mutations different from p53 mutations in adjacent areas of clonally expanded non-neoplastic keratinocytes. Oncogene 12: 765-773.

Robles AI, Rodriguez-Puebla ML, Glick AB, Trempus C, Hansen L, Sicinski P, Tennant RW, Weinberg RA, Yuspa SH, Conti CJ. 1998. Reduced skin tumor development in cyclin D1-deficient mice highlights the oncogenic ras pathway in vivo. Genes Dev 12: 2469-2474.

Rogers HW, Weinstock MA, Harris AR, Hinckley MR, Feldman SR, Fleischer AB, Coldiron BM. 2010. Incidence estimate of nonmelanoma skin cancer in the United States, 2006. Arch Dermatol 146: 283-287.

Rorke EA, Adhikary G, Jans R, Crish JF, Eckert RL. 2010. AP1 factor inactivation in the suprabasal epidermis causes increased epidermal hyperproliferation and hyperkeratosis but reduced carcinogen-dependent tumor formation. Oncogene 29: 5873-5882. 
P.Y. Huang and A. Balmain

Rounbehler RJ, Schneider-Broussard R, Conti CJ, Johnson DG. 2001. Myc lacks E2F1's ability to suppress skin carcinogenesis. Oncogene 20: 5341-5349.

Saez E, Rutberg SE, Mueller E, Oppenheim H, Smoluk J, Yuspa SH, Spiegelman BM. 1995. C-fos is required for malignant progression of skin tumors. Cell 82: 721-732.

Schepers AG, Snippert HJ, Stange DE, van den Born M, van Es JH, van de Wetering M, Clevers H. 2012. Lineage tracing reveals $\mathrm{Lgr}^{+}$stem cell activity in mouse intestinal adenomas. Science 337: 730-735.

Schioppa T, Moore R, Thompson R, Rosser E, Kulbe H, Nedospasov S, Mauri C, Coussens L, Balkwill F. 2011. B regulatory cells and the tumor-promoting actions of TNF- $\alpha$ during squamous carcinogenesis. Proc Natl Acad Sci 10662-10667.

Scholl FA, Dumesic PA, Barragan DI, Charron J, Khavari PA. 2009a. Mek1/2 gene dosage determines tissue response to oncogenic Ras signaling in the skin. Oncogene 28: 1485 1495.

Scholl FA, Dumesic PA, Barragan DI, Harada K, Charron J, Khavari PA. 2009b. Selective role for Mek1 but not Mek2 in the induction of epidermal neoplasia. Cancer Res 69: 3772-3778.

Schramek D, Leibbrandt A, Sigl V, Kenner L, Pospisilik JA, Lee HJ, Hanada R, Joshi PA, Aliprantis A, Glimcher L, et al. 2010. Osteoclast differentiation factor RANKL controls development of progestin-driven mammary cancer. Nature 468: 98-102.

Schweizer J, Marks F. 1977. Induction of the formation of new hair follicles in mouse tail epidermis by the tumor promoter 12-O-tetradecanoylphorbol-13-acetate. Cancer Res 37: 4195-4201.

Segrelles C, Lu J, Hammann B, Santos M, Moral M, Cascallana JL, Lara MF, Rho O, Carbajal S, Traag J, et al. 2007. Deregulated activity of Akt in epithelial basal cells induces spontaneous tumors and heightened sensitivity to skin carcinogenesis. Cancer Res 67: 10879-10888.

She Q, Chen N, Bode AM, Flavell RA, Dong Z. 2002. Deficiency of c-Jun-NH2-terminal kinase-1 in mice enhances skin tumor development by 12-O-tetradecanoylphorbol13-acetate. Cancer Res 62: 1343-1348.

Sibilia M, Fleischmann A, Behrens A, Stingl L, Carroll J, Watt FM, Schlessinger J, Wagner EF. 2000. The EGF receptor provides an essential survival signal for SOS-dependent skin tumor development. Cell 102: 211-220.

Skeen JE, Bhaskar PT, Chen C-C, Chen WS, Peng X, Nogueira V, Hahn-Windgassen A, Kiyokawa H, Hay N. 2006. Akt deficiency impairs normal cell proliferation and suppresses oncogenesis in a p53-independent and mTORC1dependent manner. Cancer Cell 10: 269-280.

Steck P, Pershouse M, Jasser S, Yung W, Lin H, Ligon A, Langford L, Baumgard M, Hattier T, Davis T, et al 1997. Identification of a candidate tumour suppressor gene, MMAC1, at chromosome 10q23.3 that is mutated in multiple advanced cancers. Nat Genet 15: 356-362.

Stransky N, Egloff AM, Tward AD, Kostic AD, Cibulskis K, Sivachenko A, Kryukov GV, Lawrence MS, Sougnez C, McKenna A, et al. 2011. The mutational landscape of head and neck squamous cell carcinoma. Science 333: $1157-1160$.

Strid J, Roberts SJ, Filler RB, Lewis JM, Kwong BY, Schpero W, Kaplan DH, Hayday AC, Girardi M. 2008. Acute up- regulation of an NKG2D ligand promotes rapid reorganization of a local immune compartment with pleiotropic effects on carcinogenesis. Nat Immunol 9: 146-154.

Suganuma M, Okabe S, Marino MW, Sakai A, Sueoka E, Fujiki H. 1999. Essential role of tumor necrosis factor $\alpha$ (TNF- $\alpha$ ) in tumor promotion as revealed by TNF- $\alpha$-deficient mice advances in brief. Cancer Res 59: 4516-4518.

Suzuki A, Itami S, Ohishi M. 2003. Keratinocyte-specific Pten deficiency results in epidermal hyperplasia, accelerated hair follicle morphogenesis and tumor formation. Cancer Res 63: 674-681.

Swamy M, Jamora C, Havran W, Hayday A. 2010. Epithelial decision makers: In search of the "epimmunome." Nat Immunol 11: 656-665.

The Cancer Genome Atlas Research Network. 2012. Comprehensive genomic characterization of squamous cell lung cancers. Nature 489: 519-525.

Tiano HF, Loftin CD, Akunda J, Lee CA, Spalding J, Sessoms A, Dunson DB, Rogan EG, Morham SG, Smart RC, et al. 2002. Deficiency of either cyclooxygenase (COX)-1 or COX-2 alters epidermal differentiation and reduces mouse skin tumorigenesis. Cancer Res 62: 3395-3401.

Van Duuren BL, Sivak A, Katz C, Seidman K, Melchionne S. 1975. The effect of aging and interval between primary and secondary treatment in two-stage carcinogenesis on mouse skin. Cancer Res 35: 502-505.

Van Kranen HJ, De Gruijl FR. 1999. Mutations in cancer genes of UV-induced skin tumors of hairless mice. J Epidemiol 9: 58-65.

Van Kranen HJ, de Gruijl FR, de Vries A, Sontag Y, Wester PW, Senden HC, Rozemuller E, van Kreijl CF. 1995. Frequent p53 alterations but low incidence of ras mutations in UV-B-induced skin tumors of hairless mice. Carcinogenesis 16: 1141-1147.

Vassar R, Rosenberg M, Ross S, Tyner A, Fuchs E. 1989. Tissue-specific and differentiation-specific expression of a human K14 keratin gene in transgenic mice. Proc Natl Acad Sci 86: 1563-1567.

Vassar R, Hutton ME, Fuchs E. 1992. Transgenic overexpression of transforming growth factor bypasses the need for c-Ha-ras mutations in mouse skin tumorigenesis. $\mathrm{Mol}$ Cell Biol 12: 4643-4653.

Vermeulen L, Morrissey E, van der Heijden M, Nicholson AM, Sottoriva A, Buczacki S, Kemp R, Tavare S, Winton DJ. 2013. Defining stem cell dynamics in models of intestinal tumor initiation. Science 342: 995-998.

Viaje A, Slaga TJ, Wigler M, Weinstein IB. 1977. Effects of antiinflammatory agents on mouse skin tumor promotion, epidermal DNA synthesis, phorbol esterinduced cellular proliferation, and production of plasminogen activator. Cancer Res 37: 1530-1536.

Waikel RL, Kawachi Y, Waikel PA, Wang XJ, Roop DR. 2001. Deregulated expression of c-Myc depletes epidermal stem cells. Nat Genet 28: 165-168.

Wakabayashi Y, Mao J-H, Brown K, Girardi M, Balmain A. 2007. Promotion of Hras-induced squamous carcinomas by a polymorphic variant of the Patched gene in FVB mice. Nature 445: 761-765.

Wang Z, Pedersen E, Basse A, Lefever T, Peyrollier K, Kapoor S, Mei Q, Karlsson R, Chrostek-Grashoff A, Brakebusch C. 2010. Racl is crucial for Ras-dependent skin tumor 
Modeling Cutaneous SCC

formation by controlling Pak1-Mek-Erk hyperactivation and hyperproliferation in vivo. Oncogene 29: 3362-3373.

Wang NJ, Sanborn Z, Arnett KL, Bayston LJ, Liao W, Proby CM, Leigh IM, Collisson EA, Gordon PB, Jakkula L, et al. 2011. Loss-of-function mutations in Notch receptors in cutaneous and lung squamous cell carcinoma. Proc Natl Acad Sci 108: 17761-17766.

White AC, Tran K, Khuu J, Dang C, Cui Y, Binder SW, Lowry WE. 2011. Defining the origins of Ras/p53-mediated squamous cell carcinoma. Proc Natl Acad Sci 108: $7425-7430$.

Winton DJ, Blount MA, Ponder BA. 1989. Polyclonal origin of mouse skin papillomas. Br J Cancer 60: 59-63.

Wong CE, Yu JS, Quigley DA, To MD, Jen K-Y, Huang PY, Del Rosario R, Balmain A. 2013. Inflammation and Hras signaling control epithelial-mesenchymal transition during skin tumor progression. Genes Dev 27: 670-682.

Young MR, Li JJ, Rincón M, Flavell RA, Sathyanarayana BK, Hunziker R, Colburn N. 1999. Transgenic mice demonstrate AP-1 (activator protein-1) transactivation is re- quired for tumor promotion. Proc Natl Acad Sci 96: 9827-9832.

Youssef KK, Van Keymeulen A, Lapouge G, Beck B, Michaux C, Achouri Y, Sotiropoulou PA, Blanpain C. 2010. Identification of the cell lineage at the origin of basal cell carcinoma. Nat Cell Biol 12: 299-305.

Yu H, Kortylewski M, Pardoll D. 2007. Crosstalk between cancer and immune cells: Role of STAT3 in the tumour microenvironment. Nat Rev Immunol 7: 41-51.

Yuspa SH. 2000. Overview of carcinogenesis: Past, present and future. Carcinogenesis 21: 341-344.

Zagouras P, Stifani S, Blaumueller C, Carcangiu M, Artavanis-Tsakonas S. 1995. Alterations in Notch signaling in neoplastic lesions of the human cervix. Proc Natl Acad Sci 92: 6414-6418.

Zenz R, Scheuch H, Martin P, Frank C, Eferl R, Kenner L, Sibilia M, Wagner EF. 2003. c-Jun regulates eyelid closure and skin tumor development through EGFR signaling. Dev Cell 4: 879-889. 


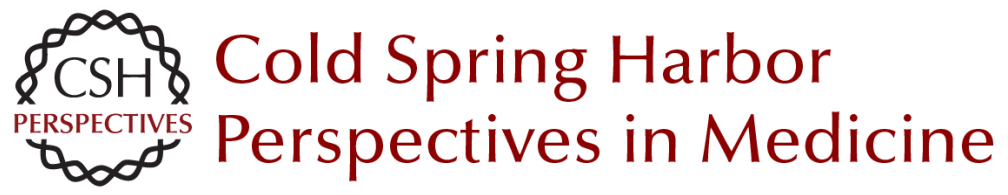

\section{Modeling Cutaneous Squamous Carcinoma Development in the Mouse}

Phillips Y. Huang and Allan Balmain

Cold Spring Harb Perspect Med 2014; doi: 10.1101/cshperspect.a013623

Subject Collection The Skin and Its Diseases

Melanoma: Clinical Features and Genomic Insights

Elena B. Hawryluk and Hensin Tsao

Wound Healing and Skin Regeneration

Makoto Takeo, Wendy Lee and Mayumi Ito

The Dermal Papilla: An Instructive Niche for

Epithelial Stem and Progenitor Cells in

Development and Regeneration of the Hair Follicle Bruce A. Morgan

Immunology and Skin in Health and Disease Jillian M. Richmond and John E. Harris

Desmosomes: Regulators of Cellular Signaling and Adhesion in Epidermal Health and Disease Jodi L. Johnson, Nicole A. Najor and Kathleen J. Green

Markers of Epidermal Stem Cell Subpopulations in Adult Mammalian Skin Kai Kretzschmar and Fiona M. Watt

Psoriasis Paola Di Meglio, Federica Villanova and Frank O. Nestle

Cell Therapy in Dermatology Gabriela Petrof, Alya Abdul-Wahab and John A. McGrath
Modeling Cutaneous Squamous Carcinoma

Development in the Mouse

Phillips Y. Huang and Allan Balmain

Natural and Sun-Induced Aging of Human Skin Laure Rittié and Gary J. Fisher

Advanced Treatment for Basal Cell Carcinomas Scott X. Atwood, Ramon J. Whitson and Anthony E. Oro

Epidermal Polarity Genes in Health and Disease Frederik Tellkamp, Susanne Vorhagen and Carien M. Niessen

Induced Pluripotent Stem Cells in Dermatology:

Potentials, Advances, and Limitations Ganna Bilousova and Dennis R. Roop

The Genetics of Human Skin Disease Gina M. DeStefano and Angela M. Christiano

p53/p63/p73 in the Epidermis in Health and Disease

Vladimir A. Botchkarev and Elsa R. Flores

Diversification and Specialization of Touch

Receptors in Skin

David M. Owens and Ellen A. Lumpkin

For additional articles in this collection, see http://perspectivesinmedicine.cshlp.org/cgi/collection/ 